\title{
Liberia: Enhanced Initiative for Heavily Indebted Poor Countries- Preliminary Document
}

This paper was prepared by staff of the International Monetary Fund and the World Bank in connection with the Executive Board's consideration of Liberia preliminary assessment of eligibility for assistance under the Enhanced Initiative for Heavily Indebted Poor Countries. It is based on the information available at the time it was completed on January 15, 2008. The views expressed in this document are those of the staff team and do not necessarily reflect the views of the government of Liberia or the Executive Board of the IMF.

The policy of publication of staff reports and other documents by the IMF allows for the deletion of market-sensitive information.

To assist the IMF in evaluating the publication policy, reader comments are invited and may be sent by e-mail to publicationpolicy@imf.org.

Copies of this report are available to the public from

International Monetary Fund $\bullet$ Publication Services

$70019^{\text {th }}$ Street, N.W. $\bullet$ Washington, D.C. 20431

Telephone: (202) 623-7430 • Telefax: (202) 623-7201

E-mail: publications@imf.org • Internet: http://www.imf.org

Price: $\$ 18.00$ a copy

\section{International Monetary Fund} Washington, D.C. 



\title{
INTERNATIONAL DEVELOPMENT ASSOCIATION AND \\ INTERNATIONAL MONETARY FUND
}

\section{LIBERIA \\ Enhanced Heavily Indebted Poor Countries (HIPC) Initiative Preliminary Document}
Prepared by the Staffs of the International Development Association and the International Monetary Fund

\begin{abstract}
Approved by Danny Leipziger and Obiageli K. Ezekwesili (IDA) and Matthew Fisher and David Andrews (IMF)
\end{abstract}

January 15,2008

Contents

Page

I. Introduction 6

II. Background And Eligibility for HIPC Initiative Assistance ............................................... 7
A. PRGF and IDA Status 7
B. Country Background and Political Developments ........................................................ 7
C. Post-Conflict Macroeconomic Track Record.......................................................... 8

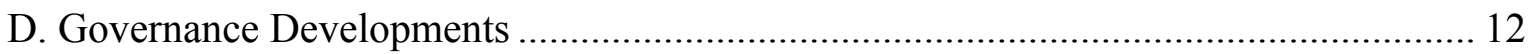

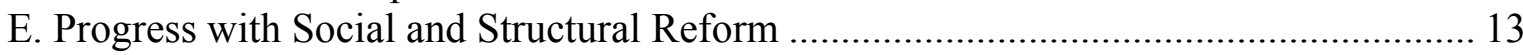

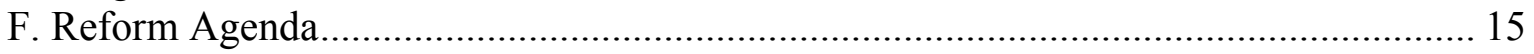

III. Medium- to Long-Term Strategy and Prospects................................................................ 16

A. Macroeconomic Framework and Prospects ............................................................ 16

B. The I-PRSP Reform Strategy ……………………….............................................. 18

IV. Debt Relief Analysis and Possible HIPC, MDRI and beyond-HIPC Assistance ............. 19

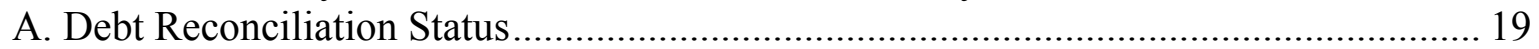

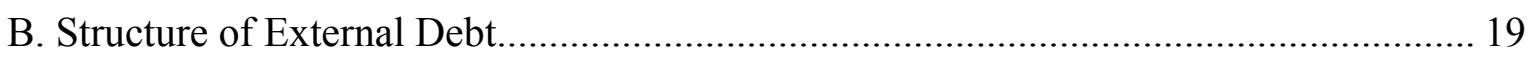

C. Arrears Clearance Strategy............................................................................... 20

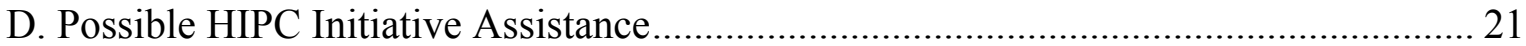

E. Expected Impact of Debt Relief on Liberia's Debt Ratios............................................ 24

F. Debt Relief Under MDRI and Possible Bilateral and Multilateral beyond-HIPC

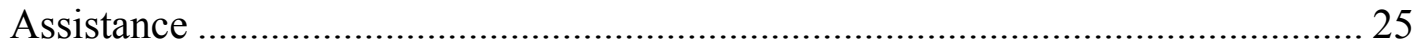

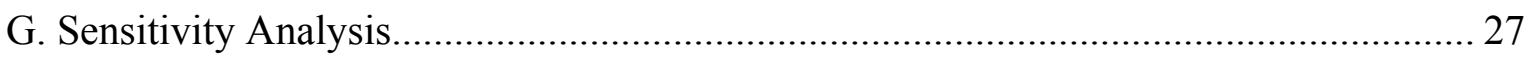


V. The Decision and Floating Completion Points ....................................................... 29

A. Possible Decision Point Timing .............................................................................. 29

B. Possible Triggers for the Floating Completion Point................................................. 29

C. Monitoring Public Spending Following Provision of HIPC Assistance ....................... 29

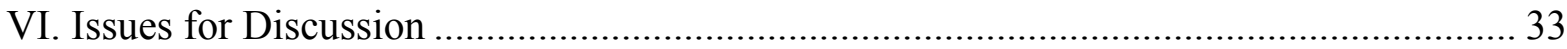

Tables

1. Liberia: Selected Economic and Financial Indicators, 2004-08 .....................................10

Boxes

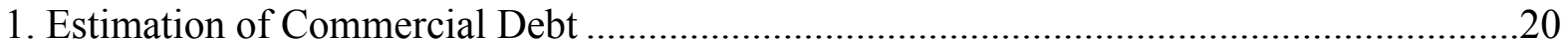

2. Key Macroeconomic Assumptions Underlying the Debt Relief Analysis .........................26

3. Possible Triggers for Liberia's Floating Completion Point..............................................30

4. Possible Medium-Term Expenditure Priorities .............................................................33

Annexes

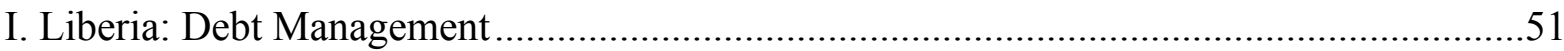

II. Liberia: Proposed Methodology for Imputing Value of Services Receipts ......................55 


\section{EXECUTIVE SUMMARY}

- Liberia is emerging from over twenty years of political instability. During that time real GDP per capita is estimated to have declined by 80-90 percent. Developments since the new government took office in early 2006 have been positive, with estimated real GDP growth rising from $2 \frac{1}{2}$ percent in 2004 to approximately 8 percent in 2006 , accompanied by relatively stable exchange and inflation rates. Significant progress has been made in improving public revenue collection and public financial management (PFM).

- Despite these strong improvements, dire poverty and social concerns persist. Around 80 percent of households live on less than US\$1 dollar a day, life expectancy has dropped to 42 years, and infant and maternal mortality rates are among the highest in the world.

- The preliminary Debt Relief Analysis (DRA) confirms Liberia's eligibility for debt relief under the Enhanced Heavily Indebted Poor Countries (HIPC) Initiative. Liberia's public and publicly guaranteed external debt at end-June 2007 was an estimated US\$4.8 billion in nominal terms, around 96 percent of which was in arrears. After applying traditional debt relief mechanisms, Liberia's net present value (NPV) of debt-to-exports ratio at end-June 2007 is estimated at 1,681 percent - far above the threshold under the HIPC Initiative.

- Liberia must fulfill a number of requirements to qualify for debt relief under the HIPC Initiative by reaching its decision point. While it has already prepared an Interim Poverty Reduction Strategy Paper (I-PRSP), it needs to continue implementing satisfactorily the current staff-monitored program (SMP) of uppercredit tranche policy conditionality, agree on appropriate completion point triggers, and either clear arrears to multilateral creditors or reach agreements with them on a strategy for arrears clearance.

- As of end-June 2007, the largest share of Liberia's external debt, in nominal terms and before traditional debt relief, was owed to multilateral and bilateral creditors (65.7 percent), with commercial creditors holding 34.3 percent. The IMF and IDA/IBRD were Liberia's largest creditors, representing approximately 17 percent and 9 percent of total claims, respectively. In December 2007 the clearance of arrears to IDA/IBRD and the AfDB reduced the share owed to multilateral creditors significantly.

- The reduction of Liberia's NPV of debt-to-exports ratio to 150 percent requires total HIPC debt relief of US\$2,994.7 million in end-June 2007 NPV terms, implying a common reduction factor of 91.1 percent, one of the largest common reduction factors thus far under the HIPC Initiative. 
- The sensitivity analysis highlights the vulnerability of Liberia's debt prospects. In particular, Liberia's ability to service its external debt after HIPC debt relief is found to be vulnerable to increased new borrowing even on concessional terms (which could arise, for example, if Liberia was to compensate for a possible reduction in external grants compared to the baseline), and to a combination of adverse domestic and external shocks.

- The staffs seek the Executive Directors' views and guidance on Liberia's likelihood of qualifying and reaching the decision point under the Enhanced HIPC Initiative by end-February 2008, together with the approval by the IMF Board of arrangements under the Poverty Reduction and Growth Facility (PRGF) and the Extended Fund Facility (EFF), provided that Liberia (i) has a current six-month track record of satisfactory performance under an upper-tranche conditionality program with the IMF; (ii) clears its arrears to its multilateral creditors or agrees on a strategy to clear them; and (iii) agrees on appropriate completion point triggers. The staffs also seek the Executive Directors' views on the triggers for the floating completion point. 


\section{LIST OF ACRONYMS}

\begin{tabular}{|c|c|}
\hline CBL & Central Bank of Liberia \\
\hline CMCo & Cash Management Committee \\
\hline DRA & Debt Relief Analysis \\
\hline EFF & Extended Fund Facility \\
\hline EITI & Extractive Industries Transparency Initiative \\
\hline EGSC & Economic Governance Steering Committee \\
\hline GEMAP & Governance and Economic Management Assistance Program \\
\hline HIPC & Heavily Indebted Poor Countries \\
\hline I-PRSP & Interim Poverty Reduction Strategy Paper \\
\hline LRC & Liberia Revenue Code \\
\hline LRDC & Liberia Reconstruction and Development Committee \\
\hline MDGs & Millennium Development Goals \\
\hline MDRI & Multilateral Debt Relief Initiative \\
\hline NTGL & National Transitional Government of Liberia \\
\hline PCC & Post-Conflict Countries \\
\hline PCCF & Post-Conflict Countries Facility \\
\hline PEMFAR & Public Expenditure Management and Financial Accountability Review \\
\hline PFM & Public Financial Management \\
\hline PRGF & Poverty Reduction and Growth Facility \\
\hline SMP & Staff-Monitored Program \\
\hline SOE & State-Owned Enterprise \\
\hline UNMIL & United Nations Mission in Liberia \\
\hline
\end{tabular}




\section{INTRODUCTION}

1. This paper presents a preliminary assessment of the eligibility of the Republic of Liberia (hereafter "Liberia") for assistance under the Enhanced HIPC Initiative." The assessment is based on a joint IDA/IMF staff mission to Monrovia in March-April 2007 and subsequent revision based on updated information received in October and November 2007. Together with the authorities, the staffs conducted a preliminary DRA based on a provisional reconciliation of external debt data as of end-June 2007.

2. The analysis indicates that after traditional debt relief mechanisms are applied, Liberia's NPV of debt-to-exports ratio at end-June 2007 was significantly above the HIPC Initiative threshold. Possible HIPC Initiative debt relief is estimated to be US\$2,994.7 million and Multilateral Debt Relief Initiative (MDRI) and MDRI-type, beyond HIPC relief of about US\$132.5 million in NPV terms at end-June 2007. Because Liberia has been servicing almost none of its debt, this relief would not immediately create additional fiscal space. In the medium term, however, a resolution of its arrears would give Liberia access to additional development assistance, helping it make progress toward the Millennium Development Goals (MDGs).

3. Liberia is eligible for debt relief under the HIPC Initiative but must fulfill some requirements before reaching its decision point. Liberia has already prepared an I-PRSP. Liberia must also continue satisfactorily implementing the current SMP, agree on appropriate completion point triggers, and either clear arrears to multilateral creditors or reach agreement on a strategy to clear them.

4. This paper is organized as follows. Section II provides background information on Liberia's eligibility under the HIPC Initiative, including the country's recent economic progress and current situation. Section III discusses Liberia's medium- to long-term macroeconomic framework and its poverty reduction strategy. Section IV summarizes the preliminary DRA and presents the size of possible HIPC, MDRI and MDRI-type assistance, including through arrears clearance. Section V suggests a timeline for preparing the decision point document, and outlines reforms that could serve as completion point triggers.

Section VI presents issues for discussion by Executive Directors.

\footnotetext{
1 "Enhanced HIPC Initiative" is hereafter referred to as "HIPC Initiative."
} 


\section{BACKGROUND AND EligibILITY FOR HIPC INITIATIVE ASSISTANCE}

\section{A. PRGF and IDA Status}

\section{Liberia's performance under the SMP since early 2006 has been broadly} satisfactory. The IMF Board in February and July 2007 agreed with the IMF staff's assessment that, apart from financing assurances, Liberia's SMP for 2007 is of upper-credit tranche quality. The SMP has now been extended to end-March 2008. Assuming the current SMP continues to be implemented satisfactorily, Liberia could be eligible to receive resources under a Fund-supported program once its arrears have been cleared. IMF staff and the Liberian authorities continue to discuss PRGF/EFF blend financing, which could be presented to the IMF's Executive Board now that the IMF has secured sufficient financing pledges from member countries to allow the IMF to provide debt relief to Liberia. ${ }^{3}$

\section{Liberia is an IDA-only country with a gross national per capita income of} US\$130 in 2005 (using the World Bank's Atlas methodology). Following a re-engagement strategy discussed by the IDA Board on March 9, 2004, a Joint Interim Strategy Note, prepared in collaboration with the African Development Bank (AfDB), was presented to the IDA Board on June 14, 2007. The note proposed a support program that is closely aligned with the government's I-PRSP and takes advantage of the opportunity to sustain reform momentum under the current government. The program consolidates and mainstreams the work supported by the World Bank in the areas of economic governance, infrastructure rehabilitation, and community development and that of the AfDB on governance, economic management, and infrastructure (including water supply rehabilitation). The strategy for the first time also proposes intervention in other critical sectors, such as health and civil service reform, in line with the I-PRSP. In December 2007, arrears to the World Bank were cleared with the support of a grant under a Development Policy Operation (DPO); arrears to the AfDB were also cleared in December 2007 through an operation under the framework for assisting Post-Conflict Countries (PCCs).

\section{B. Country Background and Political Developments}

\section{Thirty years ago, Liberia's per capita GDP was on par with that of Egypt,} Indonesia, and the Philippines and was more than double that of India. Between the mid-1940s and the 1960s, Liberia's economy grew at rates ranging from 4-7 percent annually. However, marginalization, mismanagement, and perceived inequalities in the distribution of benefits from national resources sowed the seeds for a 1980 coup. GDP

\footnotetext{
${ }^{2}$ See IDA and IMF, "Heavily Indebted Poor Countries (HIPC) Initiative-List of Ring-Fenced Countries that Meet the Income and Indebtedness Criteria at end-2004," April 11, 2006.

${ }^{3}$ Given that Liberia's financing needs would exceed the exceptional access limit under the PRGF, resources from the General Resources Account, expected from the EFF, would also be needed.
} 
growth fell from 5 percent in the early 1970s to less than 1 percent in the mid-1980s. After 1980, Liberia entered a protracted period of instability that included civil wars in 198996 and 2000-03. By 2003, most of the country's roads and railroads, electricity generation and transmission, and potable water and sewage systems had been destroyed.

\section{After over 20 years of instability, the Accra Comprehensive Peace Agreement} of 2003 initiated a political transition. The National Transitional Government of Liberia (NTGL), established under the peace agreement, governed Liberia until the completion of legislative and presidential elections in October-November 2005. An elected government headed by President Ellen Johnson-Sirleaf assumed office on January 16, 2006. Since the signing of the Accra Peace Agreement, more than 100,000 combatants have been demobilized and most of the displaced population, estimated at a third of the total population, has returned to its place of origin.

9. Liberia is now one of the poorest countries in Africa. Liberia's estimated real GDP per capita declined by about 80-90 percent from 1980 to 2006 . Well over three-quarters of its people now live on less than US\$1 per day; about half live on less than 50 cents per day. An overwhelming majority of Liberia's people are unemployed or employed in the informal sector. Besides the destruction of physical infrastructure during the conflict, the delivery of basic services such as health and education was completely disrupted. National and local institutions are dysfunctional and plagued by poor governance and widespread corruption.

10. Current conditions in Liberia present significant risks. Securing Liberia's fragile peace and economic recovery is a daunting challenge. A UN military force (UNMIL) of over 12,000 has established, and assumed responsibility for, security throughout the country. Although the UN and the United States are providing police officers with training to form a new Liberian national police force, quick and visible improvements in the living conditions of the Liberian population will be needed to support sustained security advances in the long term. This, in turn, will require the authorities to continue strengthening public institutions and economic governance to ensure that growth is inclusive and sustainable.

\section{Post-Conflict Macroeconomic Track Record}

\section{Performance under the SMP has been broadly satisfactory. Soon after taking} office in January 2006, the government requested IMF assistance to develop a program to support economic reconstruction so that Liberia can begin building the record of policy implementation needed to eventually resolve its arrears and debt overhang. The key objectives of the 2006 SMP were to rebuild public institutions, restore credible financial management, and accelerate structural reforms. The IMF Executive Board in February 2007 agreed that performance under the 2006 SMP had been broadly satisfactory. Directors also discussed a successor SMP for 2007, which aims to maintain macroeconomic stability, further strengthen PFM and the banking sector, and implement the government's anticorruption and domestic debt resolution strategies. Performance under the program 
through September 2007 has been broadly satisfactory. The authorities achieved all but one of the quantitative benchmarks and, despite some delays, significant progress has been made in achieving the structural benchmarks. The SMP for 2007 was extended to end-March 2008 in late 2007 in order to allow Liberia to maintain a continuous track record under a program of upper-credit tranche policy conditionality with the IMF to the HIPC decision point.

\section{Since 2005, the economy has recovered strongly, underpinned by a relatively} stable macroeconomic environment. Following modest growth of $2 \frac{1}{2}$ percent in 2004, estimated real GDP growth was about $5 \frac{1}{2}$ percent in 2005 and $73 / 4$ percent in 2006; it is projected to have increased to $91 / 2$ percent in 2007 . The recovery has been supported by a turnaround in agriculture and construction, and the impact of a large donor presence in the services sector. Nevertheless, exports have remained depressed; and timber and diamond exports, only recently released from UN sanctions, are not expected to begin making a significant contribution to growth until 2008. Inflation has mostly been in the single digits, anchored by a relatively stable exchange rate. Efforts to improve the financial position of the Central Bank of Liberia (CBL) have allowed net liquid foreign exchange reserves to accumulate modestly, to just under one month of imports, but net international reserves are still steeply negative, reflecting the CBL's large external liabilities.

\section{Fiscal policy has been formulated within the constraint of a balanced cash-based}

budget. Recognizing that unsustainable public debt makes it impossible to maintain an active fiscal policy stance, the government is pursuing a cash-based balanced budget. Accordingly, it has implemented, with donor support, an expenditure management program based on an interim commitment control system, which ensures that expenditures do not exceed available revenues and that procurement practices adhere to the Public Procurement and Concessions Act. Prioritized monthly cash plans have been prepared by line ministries and agencies to guide budget allotments and provide a framework for reducing expenditures, should the need arise. 
Table 1: Liberia: Selected Economic and Financial Indicators, 2004-08

\begin{tabular}{|c|c|c|c|c|c|}
\hline & $\begin{array}{r}2004 \\
\text { Est. }\end{array}$ & $\begin{aligned} 2005 \\
\text { Est. }\end{aligned}$ & $\begin{aligned} 2006 \\
\text { Est. }\end{aligned}$ & $\begin{array}{l}2007 \\
\text { Proj. }\end{array}$ & $\begin{array}{l}2008 \\
\text { Proj. }\end{array}$ \\
\hline & \multicolumn{5}{|c|}{ (Annual percentage change, unless otherwise indicated) } \\
\hline \multicolumn{6}{|l|}{ National income and prices } \\
\hline Real GDP & 2.6 & 5.3 & 7.8 & 9.4 & 9.5 \\
\hline Consumer prices (annual average) ${ }^{1 /}$ & 3.6 & 6.9 & 7.2 & 11.2 & 9.0 \\
\hline Consumer prices (end of period) ${ }^{1 /}$ & 7.5 & 7.0 & 8.9 & 9.5 & 8.5 \\
\hline Nominal GDP (millions of U.S. dollars) & 460.0 & 530.2 & 614.0 & 725.1 & 800.4 \\
\hline GDP deflator in U.S. dollars & 9.3 & 9.5 & 7.4 & 7.9 & 0.8 \\
\hline Real GDP per capita (constant 1992 U.S. dollars) ${ }^{21}$ & 113.9 & 116.7 & 121.0 & 126.3 & 131.5 \\
\hline \multicolumn{6}{|l|}{ External sector (U.S. dollar terms) } \\
\hline Exports of goods, f.o.b. & -4.7 & 6.3 & 43.0 & 33.0 & 33.0 \\
\hline Imports of goods, f.o.b. & 84.4 & 24.4 & 36.5 & 19.5 & 18.9 \\
\hline Terms of trade (deterioration - ) & 4.9 & 3.9 & 49.5 & -1.6 & -2.2 \\
\hline Official exchange rate (L\$/US\$; end of period) & 54.5 & 56.5 & 59.5 & 62.5 & $\ldots$ \\
\hline Nominal effective exchange rate (end of period) & -18.4 & 3.1 & -11.6 & $\ldots$ & $\ldots$ \\
\hline Real effective exchange rate (end of period) & -14.1 & 8.3 & -5.3 & $\ldots$ & $\ldots$ \\
\hline \multicolumn{6}{|l|}{ Central government operations ${ }^{3 /}$} \\
\hline Total revenue and grants & 4.3 & 36.1 & 6.5 & 73.3 & 25.2 \\
\hline Of which: total revenue & -1.0 & 41.6 & 6.6 & 73.6 & 26.5 \\
\hline Total expenditure and net lending & -26.7 & 51.3 & -3.7 & 81.7 & 49.4 \\
\hline Of which: current expenditure & 67.6 & 40.6 & 2.2 & 73.9 & 52.6 \\
\hline capital expenditure & -90.9 & 186.9 & -40.7 & 164.1 & 26.7 \\
\hline & \multicolumn{5}{|c|}{$\begin{array}{c}\text { (Annual percentage change; beginning-period stock of money, } \\
\text { unless otherwise indicated) }\end{array}$} \\
\hline \multicolumn{6}{|l|}{ Money and banking } \\
\hline Net foreign assets & -456.0 & -96.6 & 61.7 & -51.6 & -33.4 \\
\hline Net domestic assets & 505.3 & 132.4 & -27.3 & 84.5 & 62.0 \\
\hline Net claims on government & 533.5 & 133.4 & -18.9 & 69.3 & 62.4 \\
\hline Claims on nongovernment & 21.1 & 7.2 & 17.3 & 7.0 & 8.9 \\
\hline Other items net & -49.4 & -8.3 & -25.7 & 8.1 & -9.3 \\
\hline Broad money (M2) ${ }^{4 /}$ & 49.3 & 35.7 & 34.4 & 32.8 & 28.6 \\
\hline Velocity (GDP relative to broad money) & 5.3 & 4.7 & 4.3 & 4.0 & 3.7 \\
\hline Reserve money & 31.4 & 27.2 & 23.9 & 19.4 & 20.8 \\
\hline Broad money (stocks, billions of Liberian dollars) & 4.7 & 6.4 & 8.5 & 11.4 & 14.6 \\
\hline Liberian dollar component & 2.2 & 2.8 & 3.5 & 4.3 & 5.4 \\
\hline \multirow[t]{2}{*}{ U.S. dollar component } & 2.5 & 3.6 & 5.1 & 7.0 & 9.2 \\
\hline & \multicolumn{5}{|c|}{ (Percent of GDP) } \\
\hline \multicolumn{6}{|l|}{ Central government operations ${ }^{31}$} \\
\hline Total revenue and grants & 13.6 & 16.2 & 15.0 & 22.2 & 24.3 \\
\hline Of which: total revenue & 12.9 & 16.0 & 14.8 & 21.9 & 24.3 \\
\hline Total expenditure and net lending & 11.6 & 15.4 & 12.8 & 19.9 & 26.1 \\
\hline Of which: current expenditure & 10.7 & 13.3 & 11.7 & 17.4 & 23.4 \\
\hline capital expenditure & 0.9 & 2.1 & 1.1 & 2.5 & 2.8 \\
\hline Overall fiscal balance & 2.0 & 0.8 & 2.1 & 2.2 & -1.8 \\
\hline \multicolumn{6}{|l|}{ External sector } \\
\hline Current account balance, including grants (deficit, -) & -5.6 & -13.3 & -30.8 & -28.7 & -37.6 \\
\hline Of which: public interest payments due & -11.7 & -15.6 & -16.8 & -12.1 & -12.2 \\
\hline Current account balance, excluding grants (deficit, -) & -46.7 & -63.1 & -65.6 & -60.3 & -67.2 \\
\hline Trade balance (deficit, -) & -28.7 & -34.6 & -39.6 & -37.1 & -36.3 \\
\hline Exports, f.o.b. & 22.6 & 20.8 & 25.7 & 28.9 & 34.9 \\
\hline Imports, f.o.b. & -51.3 & -55.4 & -65.3 & -66.1 & -71.2 \\
\hline \multirow[t]{2}{*}{ Public sector external debt outstanding (total) } & 812.0 & 690.3 & 710.2 & 625.5 & 293.2 \\
\hline & \multicolumn{5}{|c|}{ (Millions of U.S. dollars, unless otherwise indicated) } \\
\hline Current account balance including grants (deficit, -) & -25.6 & -70.4 & -189.3 & -207.8 & -300.8 \\
\hline Trade balance (deficit, -) & -132.2 & -183.2 & -243.1 & -269.4 & -290.5 \\
\hline Gross official reserves & 5.3 & 7.8 & 46.1 & 60.6 & 62.1 \\
\hline (months of imports of goods and services) & 0.2 & 0.2 & 1.0 & 1.1 & 0.9 \\
\hline
\end{tabular}

Sources: Liberian authorities; and IMF staff estimates and projections.

1/ Technical adjustments were made to the CPI in 2004 in light of the substitution of some items in the CPI survey in mid-2004. 2/ The U.S. dollar-denominated GDP deflator is derived mainly from the change in the domestic CPI, the L\$/US\$ exchange rate, and international commodity prices in a few selected sub-sectors.

$3 /$ Fiscal year basis (July-June). Commitment basis starting in 2006/07.

4/ Defined as Liberian currrency outside banks plus demand, time, and savings deposits in Liberian and U.S. dollars. 


\section{Strengthened tax administration and progress with fiscal management have boosted revenues, although public expenditure management needs further} strengthening. The government's efforts in tax and customs administration have enhanced efficiency and widened the tax base. While customs continued to be the main source of revenue, revenues from income taxes have increased substantially and account for about 30 percent of all revenues. Revenue measures taken since 2005 include (i) increasing the penalty for not inspecting imports before shipment; (ii) eliminating noncash payments of taxes; (iii) better managing import tax exemptions, including those granted to nongovernmental organizations and others, to limit abuses; (iv) redefining the base for the goods and services tax on imports in accordance with the Liberia Revenue Code (LRC); (v) raising the selective tax rate on restaurant services from 3.5 to 7.0 percent; and (vi) increasing the excise tax on beer and cigarettes and eliminating the distinction between imported and domestic products in applying excise taxes. The government is carrying out a tax reform strategy that would lower tax rates while broadening the tax base. Expenditure approvals lagged available cash resources for most of fiscal year 2006/07, reflecting the following factors: the legislature's late approval of the 2006/07 budget, ${ }^{4}$ continued challenges in implementing the new procurement act, and capacity constraints in line ministries. Expenditure approvals accelerated in the last two months of the fiscal year, but required significant budgetary transfers between budget line items, highlighting the need for the expenditure approval process to be improved so that expenditures are not concentrated at the fiscal year's end and to create an institutional framework that ensures the fiscal outturn is consistent with the approved budget. The authorities have taken some recent steps to strengthen budget implementation, including measures requiring that the Budget Committee chaired by the Minister of Finance approve all transfers between budget lines and that major budgetary transfers are also approved by the president and the legislature. ${ }^{5}$

\section{The government has begun implementing its domestic debt resolution strategy.}

In January 2007, the authorities finalized a domestic debt resolution strategy. Total outstanding claims of US\$914 million were reviewed with the assistance of an external auditor; US $\$ 304$ million of this total was considered valid and the remainder was classified as either "contestable" or "rejected." Valid claims were discounted by increasing percentages depending on the amount ( 0 percent for claims below US $\$ 1,000$ to about 88 percent for claims above US $\$ 1$ million). ${ }^{6}$ While discussions with some creditors, including state-owned

\footnotetext{
${ }^{4}$ While the 2006/07 budget was submitted before the end of the previous fiscal year, consistent with the SMP benchmark, the legislature did not approve it until late August. As a result, the CMCo was unable to approve any commitments in the first two months of the fiscal year. The 2007/08 budget was approved more than one month into the fiscal year resulting in an accumulation of a surplus in the first quarter of 2007/08.

${ }^{5}$ A major budgetary transfer is defined as a transfer between ministries, agencies or branches of government which totals 30 percent of the affected institution's appropriation on a cumulative basis.

${ }^{6}$ Special consideration was given to debt owed to the CBL (over 90 percent of the total debt) and other financial institutions given ongoing efforts to strengthen the financial system.
} 
enterprises (SOEs), are ongoing, payments to small claimants began in 2006/07; payments to the CBL and private banks began in the first half of 2007/08. Owing to scarcity of government resources and significant development priorities, it is envisioned that payments on these domestic debt claims would span 30 years.

16. The CBL has taken steps to strengthen the monetary policy framework and the banking sector, while improving its own financial position. The policy framework recognizes the current limited scope for an active monetary policy, given the high degree of dollarization, and focuses on maintaining low and stable inflation by targeting broad exchange rate stability. Much progress has been made in improving bank capitalization, but the banking system remains fragile and needs stronger supervision. Progress has also been made in improving the financial position of the CBL and in strengthening financial management and processes. The CBL is targeting a small budget surplus for 2007.

\section{Governance Developments}

17. Governance weaknesses pose a major challenge. Many of the civil servants and staff of SOEs recruited in the past two decades were unqualified and poorly educated patronage appointees. External audits during the NTGL revealed malfeasance and poor PFM.

\section{In September 2005, the NTGL and its international partners signed the} Governance and Economic Management Assistance Program (GEMAP). GEMAP is a direct response to the concerns of the government and partners about the mismanagement of public resources in the post-conflict transition and its threat to the peace process. An Economic Governance Steering Committee (EGSC), chaired by the president and comprising administration officials, CBL authorities, international partners and civil society, oversees the implementation of GEMAP.

19. GEMAP has six components: (i) securing Liberia's revenue base, (ii) improving budgeting and expenditure management, (iii) improving procurement practices and the granting of concessions, (iv) establishing processes to control corruption, (v) supporting institutions that are key to promoting and sustaining government accountability and good financial management, and (vi) capacity building.

20. The government has made good progress in implementing GEMAP. It has strengthened public revenues and expenditure management, reinforced financial controls at SOEs, adopted a zero-tolerance policy on corruption, made good progress on eliminating ghost workers in the civil service, drafted a Civil Service Code of Conduct, and required all serving Cabinet members to publicly declare their assets.

\section{The authorities approved an anticorruption strategy in December 2006 that} provides, inter alia, for establishing an independent anticorruption commission. The strategy is based on four main pillars: (i) strengthening governance rules and procedures; (ii) reinforcing institutions; (iii) amending laws on corruption; and (iv) ensuring consultation 
with all sectors of society. They also ratified the UN and African Union conventions against corruption and began implementing measures to strengthen governance. Draft legislation to establish the independent anticorruption commission has been submitted to the legislature.

22. Liberia has begun addressing long-standing problems in financial management and economic governance. Key achievements include (i) deploying international experts and financial controllers with co-signing authority to revenue-generating agencies and the CBL; (ii) enforcing preshipment inspections for imports and exports; (iii) strictly enforcing the Liberia Revenue Code; (iv) empowering the cash management committee (CMCo) to limit expenditures to available cash revenues; (v) completing a review of all concessions and contracts signed by the NTGL; (vi) finalizing and beginning implementation of a domestic debt strategy; (vii) strengthening financial management at the CBL; and (viii) implementing actions to enable UN sanctions on diamond and timber exports to be lifted.

\section{However, significant challenges remain in establishing a transparent and} accountable government. While some PFM improvements have been made, budget implementation remains a challenge. The government must integrate the new procurement rules into all its systems, execute the budget more transparently, enhance governance within agencies and SOEs, and strengthen the tracking of aid commitments and flows. Capacity building, already difficult because staff education and training are limited, has faced further difficulties due to the need to develop and implement adequate new controls and monitoring systems in the chain of expenditure. The government needs to improve its systems, particularly for procurement and internal audits, throughout all its ministries. If the scope for corruption is not reduced, much of the public expenditure donors finance will continue to be executed outside the government's budget. Furthermore, a medium-term fiscal framework which incorporates data on donor flows must be developed to guide budget preparation and ensure its consistency with the government's I-PRSP and the PRSP under preparation. A Public Expenditure Management and Financial Accountability Review (PEMFAR), currently underway and led by the World Bank and IMF, aims to help the government address many of these issues. ${ }^{7}$

\section{The lack of reliable and timely data constrains the government's ability to} formulate policies and monitor their implementation. A key challenge will be to formulate a national strategy for the development of the statistical system and to strengthen the capacity of the Liberian Institute for Statistics and Geo-Information Services.

\section{E. Progress with Social and Structural Reform}

\section{Despite Liberia's recent rebound in economic growth, the poverty and social} situation remains dire. A survey on poverty by the UNDP shows that roughly 80 percent of

\footnotetext{
${ }^{7}$ Some of the proposals discussed were developed by the government in a July 2007 Budget Cycle Workshop.
} 
all households live on US\$1 a day or less. ${ }^{8}$ Life expectancy has dropped to 42 years, below the average for low income countries under stress. Infant mortality is around 157 per 1,000 live births and child mortality around 235 per 1,000 live births. Maternal mortality is among the highest in the world (790 women per 100,000 live births). Preventable diseases, such as malaria, diarrhea, respiratory infections, and measles, are rife. Malnutrition is considered a key factor in high death rates. Most medical clinics ( 80 percent) are supported by humanitarian organizations; along with the closure of camps for internally displaced people, the withdrawal of such relief providers will reduce social services. In education, the school system is unable to absorb the large numbers of children who have enrolled in primary schools since the new government abolished school fees. Even as progress is made at the policy and ministerial level, delivering services at the local level will be a daunting challenge.

\section{Recent surveys supported by}

UNDP and FAO/WHO show that many households face food insecurity and lack access to basic services. Indeed, 11 percent of surveyed households were food insecure, 40 percent were highly vulnerable to food insecurity, 41 percent were moderately vulnerable to food insecurity, and only 9 percent were food secure. Access to basic services, including water and sanitation, are also limited (only 32 percent of surveyed households had access to improved water sources and 24 percent to sanitary communal latrines).

\section{The initial 150-Day Action Plan}

Note: Percent of total populations, unless otherwise indicated

allowed the government to make a strong start in rebuilding the country's infrastructure and social services. The government began rehabilitating several hundred kilometers of roads and a few bridges; rehabilitated about 36 high schools, 39 clinics, and 4 community health facilities; financed community development projects in all 15 counties; began to rebuild the electricity grid within Monrovia; strengthened the national health strategy to fight HIV/AIDS and provided bed nets in malaria endemic communities as well as medicines for new tuberculosis cases; rehabilitated water pipelines in parts of Monrovia; constructed 100 new water points and 52 new boreholes around the country; initiated reforms in the education sector and rehabilitated several schools; and increased budgetary outlays for health to 8.9 percent of the

\footnotetext{
${ }^{8}$ UNDP, Poverty Profile of Liberia, January 2001.
} 
budget and education to 8.6 percent. The action plan fed into the I-PRSP, the implementation of which is underway.

28. Agriculture is a major component of economic revitalization. Agriculture is the primary source of livelihood for most of the population. Many households reverted to subsistence farming during the war. Yet few resources are available to smallholders, and the poor transportation network makes it hard for farmers to get products to market. Recovery has been quicker in the commercial plantation sector because the high price of rubber has spurred investment. The government's strategy focuses on efforts to increase yields and production in key cash and export crops utilizing both small-holder and commercial plantation sectors. It also supports measures to create efficient supply chains and more opportunity for value-added and off-farm employment, including the necessary infrastructure for cash and export crops. The government needs to implement improved plantation concession agreements to prevent the abuses of the past from being repeated.

29. The government has also taken steps to strengthen forest sector management. Reforming the forestry sector was a requirement not only for lifting the sanctions on timber but also for ensuring that the sector is managed in a sustainable manner and benefits the population. A UN/Government of Liberia Rubber Plantation Task Force was instituted to ensure government-owned plantations are properly administered on an interim basis pending their privatization or return to the original owners.

30. Government and donors are working together on a national health plan to address systemic deficiencies, to attract additional investments in infrastructure and human resource development, and to fund recurrent expenditures. Community-based development is strengthening social capital and addressing some of the causes of conflict. The government is also working to ensure that its spending is increasingly pro-poor. As more donor financing flows through the government budget, safeguards will need to ensure that poverty-reduction spending makes up an increased proportion of total expenditures.

\section{F. Reform Agenda}

31. The government's medium-term policy framework, defined in its I-PRSP, aims to promote rapid economic growth, create jobs and secure macroeconomic stability, reduce poverty, and help Liberia make progress toward the MDGs. The program aims to strengthen governance and the rule of law by, among other measures, establishing an anticorruption commission; rebuilding national infrastructure; revitalizing the economy; and enhancing national security. Fiscal policy will focus on further strengthening PFM in the context of the medium-term framework developed to implement the poverty reduction strategy, including continued procurement reform, the implementation of a new public financial management law, and improvement in internal processes. Continued measures to strengthen revenue administration, including reorganizing and strengthening tax administration and outsourcing customs, should help further increase domestic revenues. 
Efforts in the financial sector will focus on further strengthening the monetary policy framework and enhancing private sector access to credit, including by improving banking supervision and regulations and modernizing the national payments system. On managing natural resources, the government intends to carry forward recent steps to re-establish forestry concessions and the chain of custody, observe the Kimberly process for diamonds exports, and participate in the Extractive Industries Transparency Initiative (EITI). Creating and carrying out a national statistical plan will strengthen statistical capacity, including improved estimates of national accounts, supporting policy formulation and outcome tracking. Continued financial and technical support from donors will be essential to all these efforts.

\section{Medium- to Long-Term Strategy and Prospects ${ }^{9}$}

\section{A. Macroeconomic Framework and Prospects}

\section{Real output growth is projected to average about $5 \frac{3}{4}$ percent over the}

period 2008-27. In 2008-11, real output growth should strengthen sharply as security conditions improve further, strong external support continues, and private sector-led investment in key export sectors (forestry and mining) increases. Over the long term, real output growth is expected to stabilize at about 4 percent, bringing per capita GDP close to its 1980 level by about 2027. ${ }^{10}$ The projections for real output growth assume that security holds, political and macroeconomic stability is sustained, progress is made on economic governance, and improvements in social and economic infrastructure support higher private investment, including foreign direct investment.

\section{Macroeconomic stability is expected to be supported by a prudent fiscal policy.}

The government plans to continue targeting a cash-based balanced budget in the near term. In the context of an appropriate debt-management strategy, the government in the medium term is expected to maximize access to grants and to continue seeking external financing on concessional terms. This should allow pro-poor spending and investment to increase without compromising debt sustainability. ${ }^{11}$

\footnotetext{
${ }^{9}$ The macroeconomic projections in this analysis cover the next 20 years and were prepared in consultation with the authorities. The medium-and long-term projections will be revised for the HIPC Decision Point Document, according to the prospective final agreement on arrangements under the PRGF and EFF, which are expected to cover February 2008- February 2011.

${ }^{10}$ Real output growth projections over 2008-27 are similar to those observed in 1961-70, when Liberia had significant foreign direct investment related to natural resource exploration.

${ }^{11}$ In the current projections, for illustrative purposes starting in 2011, the central government is assumed to undertake moderate deficit financing, with the overall deficit (including grants) projected to average about 3 percent of GDP over the projection period.
} 
34. Fiscal revenues (excluding grants) are projected to increase to about 26 percent of GDP in FY2026/27, from about 22 percent in FY2006/07, reflecting increased revenues from forestry and mining and continued revenue administration reforms. ${ }^{12}$ The government is expected to continue implementing measures to increase revenues, including by outsourcing customs administration, reducing exemptions through strict implementation of the LRC and reform of the investment incentive code, reforming the fiscal regime for natural resources and reorganizing and strengthening domestic tax administration. However, Liberia will continue to need donor support given its large financing needs for reconstruction.

35. Government expenditures are projected to increase to over 30 percent of GDP in FY2026/27, from about 13 percent in FY2005/06. This estimate, however, assumes that Liberia is able to continue increasing its revenues given that its borrowing capacity will likely be limited for some time. In the near term, the government is also expected to improve budget implementation while limiting public expenditure to actual revenue. More government expenditures are expected to go to strengthening institutional capacity in the public sector and to such priority areas as security, infrastructure, health, and education. The framework also assumes that the share of pro-poor spending will increase, allowing poverty to fall steadily. ${ }^{13}$

36. The external current account deficit (excluding grants) is expected to decline from 63 percent of GDP in FY2006/07 to about 22 percent of GDP in FY2026/27, mainly because of improvements in net exports. ${ }^{14}$ Exports of goods and nonfactor services, mostly in agriculture and mining, are expected to increase on average by about 13 percent annually over the projected horizon. Average growth of exports for 2007-12 is projected at about 35 percent, reflecting the lifting of UN sanctions on timber and diamond exports and significant foreign direct investment in the iron ore sector, and to average about 4 percent for the remainder of the projection period. Imports of goods and nonfactor services, meanwhile, are expected to grow, on average, by 8 percent annually, driven by economic reconstruction and investment needs.

37. The main risks to the projections are faltering progress in securing peace and stability and slower-than-expected reforms. Lack of headway in enhancing security, strengthening governance and the rule of law, and rehabilitating infrastructure and basic

\footnotetext{
${ }^{12}$ Revenue-to-GDP ratios are overstated by a probable underestimation of GDP owing to the absence of official national accounts estimates following the destruction of Liberia's statistical capacity during the civil war.

${ }^{13}$ Real GDP per capita is expected to grow, on average, by 2.4 percent a year over the projection period.

${ }^{14}$ Including grants, the current account deficit is projected to decline from 30 percent of GDP in 2006/07 to 14 percent in 2026/27.
} 
services could erode donor support, weaken confidence, and hurt private sector investment, resulting in lower-than-projected GDP growth.

\section{B. The I-PRSP Reform Strategy}

38. Liberia's provisional reform strategy is set out in its I-PRSP. ${ }^{15}$ The I-PRSP, completed in January 2007, is the result of a participatory process that included the public and other stakeholders; a deeper participatory process is underway for the full PRSP which is expected to be completed in mid-2008.

39. The Liberia Reconstruction and Development Committee (LRDC) oversees the I-PRSP's implementation and serves as a policy board. The LRDC, chaired by the president, includes key cabinet members and Liberia's international partners. The strategy period, July 2006 through June 2008, spans two annual budget cycles, thus allowing the strategy to be integrated into the budget process.

40. The I-PRSP identifies the government's key priorities for the plan period. These include (i) fully reforming the security sector; (ii) revitalizing agriculture to ensure pro-poor growth; (iii) rebuilding the road network; (iv) accelerating human resource development; (v) strengthening the environment for private sector growth; (vi) creating jobs; and (vii) promoting good governance and the rule of law.

\section{The I-PRSP is organized around four cross-sectoral and cross-ministerial} "pillars." These include (i) enhancing national security; (ii) revitalizing economic growth; (iii) strengthening governance and the rule of law; and (iv) rehabilitating infrastructure, and delivering basic services. The government is keenly aware that it will need to prioritize resource allocation within its limited budget ${ }^{16}$ and is seeking the additional donor support it will need for each pillar on the basis of its I-PRSP. The LRDC is organized around the same four cross-ministerial pillars.

42. At the Liberia Partners' Forum, held in Washington on February 13-14, 2007, development partners gave the government extensive feedback on its I-PRSP. It was agreed that the document was ambitious and reflected the government's commitment, funding permitting, to quickly address the most serious constraints to growth and poverty

\footnotetext{
${ }^{15}$ Republic of Liberia, "Breaking with the Past: from Conflict to Development: Interim Poverty Reduction Strategy," (January 2007) Country Report No. 07/60.

${ }^{16}$ The I-PRSP addresses the poor state of social services. Only 41 percent of Liberians have access to health care facilities. Of the 325 health facilities before the war, about 95 percent were partially or wholly destroyed. Only 10 percent of communities surveyed reported having a health facility within the community. Only half of school age children are able to attend school in spite of the government's Free and Compulsory Primary Education initiative. In spite of this initiative, there is concern that informal 'fees' continue to be levied.
} 
reduction. A Joint Staff Advisory Note was presented to the Executive Boards in May 2007, and the government has committed to take the comments received into account in the PRSP.

\section{Debt Relief ANALysis AND Possible HIPC, MDRI AND Beyond-HIPC ASSISTANCE $^{17}$}

\section{A. Debt Reconciliation Status}

43. The preliminary DRA below was prepared jointly by the authorities and the Bank and IMF staffs. It draws on data provided by the authorities and creditors for the public and publicly guaranteed external debt disbursed and outstanding as of end-June 2007. The reconciliation process was completed by the authorities in December 2007.

44. Liberia's preliminary DRA is based on partially reconciled external debt data. Many of the debt records of the Ministry of Finance were looted, burned or lost during the years of civil conflict. With assistance from creditors, it was possible to reconcile 100 percent of Liberia's multilateral debt and 93 percent of its bilateral debt. With donor support, the authorities have contracted an external financial advisor to reconcile commercial debt and discussions with private creditors on the reconciliation are ongoing; the preliminary DSA is based on the advisor's initial estimates of commercial debt stocks (see Box 1).

\section{B. Structure of External Debt}

45. Liberia's public and publicly guaranteed external debt was estimated at US\$4.8 billion in nominal terms at end-June 2007 (Table A1). Prior to the clearance of arrears by the World Bank and AfDB in December 2007, multilateral and bilateral creditors held approximately a two-thirds of Liberia's external debt in nominal terms before traditional debt relief (see Figure 1A). As of end-June 2007, Liberia's largest individual creditors were the IMF (17 percent of total claims) and IBRD/IDA ( 9 percent of total claims). The largest bilateral creditors are Germany and the United States (each holding 9 percent of total claims). Non-Paris Club official creditors hold approximately 3 percent of Liberia's total external debt.

46. Most of Liberia's external debt (about 96 percent) was in arrears at endJune 2007. Some 93 percent of its debt to multilateral creditors was in arrears. All multilateral maturities except some on debts owed to IDA, the African Development Fund (AfDF), the AfDB-administered Nigerian Trust Fund, IFAD, and the EU have already fallen due. All debts to commercial creditors, 91 percent of the debt to non-Paris Club bilateral creditors, and 96 percent of the debt to Paris Club bilateral creditors are in arrears.

\footnotetext{
${ }^{17}$ The Debt Relief Analysis presented in the paper is based on the HIPC Initiative's methodology.
} 


\section{Box 1. Estimation of Commercial Debt}

Many of Liberia's records on external debt were lost during the conflict years. To reconcile commercial debt, the authorities have contracted the services of an external financial advisor; the preliminary DRA is based on the advisor's initial estimates of commercial debt stocks.

To assess Liberia's eligibility for the HIPC Initiative, the staffs have used the stock of commercial debt resulting from the methodology developed by the financial advisors. It is anticipated that this methodology, which uses available records to estimate bounds for the outstanding stock of commercial debt, will also be used at the time of the decision point.

The methodology is based on the following:

- obtaining a clear segregation between outstanding principal and accumulated arrears by selecting an appropriate market interest rate and adding a set of margins that would allow the estimation of an upper and lower bound for the stock of debt (this responds to the fact that over time the principal in arrears is fixed whereas the interest in arrears is accrued);

- $\quad$ assuming that all principal amounts have been outstanding since January 1, 1984 (based on the fact that no records of new debt were found after this date);

- $\quad$ estimating past-due interest from January 1, 1984, using an appropriate market interest rate, plus a margin, on a compounding basis;

- estimating the arrears of each loan on the basis of its original currency denomination and by capitalizing the interest on the loan every six months using the relevant interest fixing date; and

- converting the resulting debt stocks to U.S. dollars at the appropriate market exchange rates.

Additional data that become available between the decision point and the completion point and are considered by the staffs to be of sufficient quality can be used at that time.

For uniformity of treatment considerations, the methodology used for estimating Liberia's stock of commercial debt would be available in the future for other countries in a similar situation (i.e., countries lacking complete records on their stock of commercial debt).

\section{Arrears Clearance Strategy}

\section{The scale of Liberia's arrears distinguishes it from all previous HIPC cases.}

Most other HIPC countries have cleared arrears before qualifying for debt relief under the initiative, given that requirements of many of the qualifying instruments for reaching the decision point involve clearing arrears to multilaterals or programming the clearance of such arrears. However, the arrears of these HIPC countries toward multilateral creditors were 
much smaller - both in absolute and relative terms - than those of Liberia. Liberia's arrears are exceptionally large relative to the size of the economy, its revenues, its exports, and multilateral creditors' possible allocations for Liberia under current rules. Liberia's situation - including arrears to the Fund - was not conducive to using those qualifying instruments.

48. Liberia's arrears to IBRD and IDA were cleared in December 2007 through a bridge loan provided by a bilateral donor. Liberia then used the proceeds of a DPO to repay the bridge loan. This operation was financed with an exceptional allocation of IDA resources, provided on grant terms.

49. Arrears to the AfDB Group were also cleared in December 2007 through an operation under the framework for assisting PCCs. Under this framework, the cost for clearing arrears is generally shared by the country, donors, and the AfDB's PCC Facility (PCCF). The proportion of the cost covered by each participant was determined on a case by case basis. For Liberia, one-third of the cost was financed by bilateral donors and two-thirds from PCCF resources. In recognition of Liberia's limited payment capacity, the country received bilateral donor assistance to finance the 1 percent contribution that would otherwise have been required from them.

50. Arrears to the IMF are expected to be cleared through a bridge loan obtained from a bilateral donor. The IMF would then be in a position to approve new financing for Liberia. The new financing by the IMF will be provided under a blend of financing from the PRGF and EFF which would be used to repay the bridge loan. Liberia is then expected to reach the HIPC decision point which would allow Liberia to begin receiving interim relief.

51. Arrears clearance with remaining multilateral creditors still needs to be agreed before Liberia reaches the decision point. The authorities are continuing discussions with the remaining multilaterals to normalize arrears on terms consistent with Liberia's limited repayment capacity. Consistent with the HIPC Initiative methodology, the grant element embedded in the clearance of arrears toward multilateral creditors will be counted toward their contribution to debt reduction under the HIPC Initiative.

\section{Possible HIPC Initiative Assistance}

\section{Liberia's debt in NPV terms, after full application of traditional debt relief} mechanisms, is an estimated US\$3,288.0 million (as of end-June 2007). This is equivalent to 1,681 percent of exports of goods and services. ${ }^{18}$ Liberia is thus eligible for debt relief

\footnotetext{
${ }^{18}$ The NPV of debt-to-export ratio is calculated using a backward-looking three-year average of exports of goods and services, using staff estimates of services receipts (Annex II). The figure for 2006 of exports of goods and services is still preliminary.
} 
under the HIPC Initiative's export window, based on end-June 2007 data, having an NPV of debt-to-exports ratio above the 150 percent threshold. ${ }^{19}$

53. The reduction of Liberia's NPV of debt-to-exports ratio from 1,681 percent to 150 percent would require HIPC debt relief of US\$2,994.7 million in end-June 2007 NPV terms. This implies a common reduction factor of 91.1 percent after traditional debt relief, one of the largest common reduction factors thus far under the HIPC Initiative. Accordingly, of the US\$2,994.7 million in debt relief (NPV terms), multilateral creditors would contribute approximately US\$1,435.2 million and bilateral and commercial creditors about US\$1,559.5 million. If we assume the time line and modalities presented below, this translates into about US\$4,208.6 million of nominal debt service relief over time, compared with payments that would have been required following the assumed application of traditional debt relief and arrears clearance from multilateral creditors.

\section{The following assumptions were made in projecting the time line of possible HIPC Initiative assistance using end-June 2007 data with a decision point by end- February 2008:}

- IDA would provide its share of total HIPC debt relief amounting to US\$377.6 million in NPV terms through the grant used to clear Liberia's arrears to both IBRD and IDA plus some additional debt-service reduction on debt outstanding and disbursed as of June 30, 2007 to be delivered through interim assistance and upon arrival at HIPC completion point. $^{20} 21$

- IMF assistance would total US\$737.0 million in NPV terms of which US\$32.9 million would be delivered through the concessional element in the use of PRGF resources during a three-year interim period, and would count toward the IMF's contribution to HIPC assistance. Immediately after the decision point is approved by the Boards of IDA

\footnotetext{
${ }^{19}$ Although Liberia meets qualifying criteria for both the export and revenue windows, the export window results in greater debt relief than the revenue window. Based on the current data, qualifications under the fiscal window would provide HIPC debt relief of US\$2,920.9 million, implying a slightly lower common reduction factor of 88.8 percent. Countries qualifying for HIPC Initiative debt relief through the fiscal revenue window may receive debt relief based on a common reduction factor sufficient to reduce the NPV of debt-to-fiscal revenues to 250 percent when this will result in more debt relief than a common reduction factor based on qualification through the export window (which reduces the NPV of debt-to-exports to 150 percent). To qualify for the fiscal revenue window, governments must have an export-to-GDP ratio of at least 30 percent and a fiscal revenue-to-GDP ratio of at least 15 percent.

${ }^{20}$ Arrears were cleared in December 2007.

${ }^{21}$ Most of IDA's HIPC Initiative debt relief has been delivered through the clearance of arrears. At the time Liberia reaches the decision point, IDA staff will seek approval from IDA's Executive Directors to the one-third NPV limit on IDA's interim debt relief being applied to the balance of IDA's HIPC Initiative debt relief to be delivered through debt service reduction. A similar treatment was granted to the Democratic Republic of Congo and later extended to Haiti and the Central African Republic to ensure comparable treatment.
} 
and the IMF, it is envisaged that the IMF would disburse HIPC interim assistance to cover for each 12-month period Liberia's forthcoming interest obligations to the IMF net of payments equivalent to Liberia's current payment capacity of about US\$60,000 per month. ${ }^{22}$

- AfDB assistance would total US\$239.6 million in NPV terms which would be fully delivered through the arrears clearance operation. ${ }^{23}$

- Assistance provided by all other multilateral creditors would total US\$80.9 million in NPV terms. Given the fiscal constraints faced by Liberia, it has been assumed that Liberia will not make payments to these other multilateral creditors until the completion point. It is then assumed that these creditors will assist Liberia to clear the total outstanding arrears at completion point through a combination of arrears clearance grants and concessional loans with additional debt-service reduction where necessary.

- Paris Club bilateral creditors are assumed to provide their share of HIPC debt relief (US\$864.1 million in NPV terms) through a flow treatment on Cologne terms-i.e., a 90 percent NPV reduction on eligible debt—after reaching the decision point, with delivery of the remaining required assistance at the completion point through a stock-ofdebt operation.

- Comparable treatment is assumed to be provided by non-Paris Club official bilateral creditors and by commercial creditors (delivery of US\$695.5 million in NPV terms of required assistance under the HIPC Initiative). ${ }^{24}$ The Liberian authorities have confirmed to staffs that the authorities intend promptly to pursue a good faith discussion with Liberia's commercial creditors in order to agree a settlement of commercial claims (possibly through an IDA Debt Reduction Facility-funded cash buyback) on financial terms that are not more generous to the commercial creditors than those outlined above.

- The high level of debt service payments due after HIPC Initiative assistance during the interim period is likely to require a further exceptional deferral of payments given Liberia's limited payment capacity.

\footnotetext{
${ }^{22}$ There will be no principal obligations falling due for the first $4 \frac{1}{2}$ years. Interest obligations falling due to the IMF during the interim period will vary due to the variable rate of charge on the EFF purchase. A higher rate of charge may require higher payments from Liberia.

${ }^{23}$ Arrears were cleared in December 2007.

24 The moratorium interest falling due after Cologne flow rescheduling for both bilateral and commercial creditors would induce a sharp increase in debt service due during the interim period (2007/08-10/11), which would be reduced after the stock of debt operation at the completion point.
} 
55. Based on these assumptions, approximately 49.0 percent of the HIPC debt relief due from multilateral creditors (US\$703.6 million in NPV terms) would be provided through financing in support of clearance of Liberia's arrears (since the grant element embedded in the clearance of arrears toward multilateral creditors is counted toward their contribution to debt reduction under the HIPC Initiative). The remaining 51.0 percent (US\$731.6 million in NPV terms) would be provided through the reduction of future debt service in the amount of US\$992.9 million in nominal terms. As a result of arrears clearance operations, Liberia's future debt service payments due to multilaterals would increase cumulatively from US\$127.3 million to US\$1,266.3 million (see Figure 2). The repayment of the IMF PRGF and EFF loans would induce a sharp increase in the debt service in FY2012/13-17/18 (there will be no principal obligations falling due for the first $4 \frac{1}{2}$ years after the decision point). However, most of this increase would be netted out by the combination of HIPC Initiative debt service reduction during the interim period and MDRItype relief at the completion point. As a result, Liberia's remaining cumulative nominal debt service payments to multilaterals after debt service reduction through the HIPC Initiative and MDRI-type relief would total to US\$55.1 million.

56. The World Bank and the AfDB are expected to provide assistance above and beyond the HIPC Initiative and MDRI relief. It is assumed that IDA will maintain strongly positive net flows to Liberia, including through grant support included in DPOs which would help meet Liberia's foreign exchange costs associated with interim period debt service. ${ }^{25}$ The AfDB is expected to provide additional grant financing that would cover Liberia's remaining interim debt service payments due. ${ }^{26}$ As a result, Liberia's debt service payments to multilaterals after debt service reduction through the HIPC Initiative, MDRI and MDRI-type relief, and additional voluntary multilateral assistance, would be further reduced to US\$38.0 million.

\section{E. Expected Impact of Debt Relief on Liberia's Debt Ratios}

57. This analysis assumes rapid economic growth, underpinned by improved security and political stability, continuous implementation of an ambitious reform agenda (particularly in the areas of economic governance and institution building capacity), and infrastructure improvements to promote private investment (Box 2). ${ }^{27}$ The framework also assumes the continuation of sound macroeconomic policies, including

\footnotetext{
${ }^{25}$ A first US\$5.0 million for such foreign exchange costs is included in the Reengagement and Reform Support Grant approved by the IDA Board in December 2007.

${ }^{26}$ Financing to cover AfDB maturities falling due during the 2008 calendar year are included as part of the AfDB arrears clearance operation.

27 The medium- and long-term projections will be revised for the HIPC decision point document, according to the prospective final agreement on arrangements under the PRGF and EFF, which are expected to cover February 2008 - February 2011.
} 
maintaining fiscal prudence while increasing revenues and seeking financial and technical donor support, as well as concessional external financing.

58. On the basis of the assumptions above and assuming the unconditional delivery of HIPC Initiative assistance, Liberia's NPV of debt-to-exports ratio is expected to decline from 150 percent as of end-June 2007 to approximately 18 percent by FY2026/27 (Table A6). The staff projection indicates that the ratio would remain consistently below the HIPC Initiative threshold of 150 percent in FY2007/08-FY2026/27. External debt service as a ratio of exports is also expected to decline gradually.

\section{F. Debt Relief Under MDRI and Possible Bilateral and Multilateral beyond-HIPC Assistance}

59. On reaching the completion point under the HIPC Initiative, Liberia would qualify for MDRI debt relief from IDA and AfDF as well as for beyond-HIPC assistance from the IMF. MDRI-type debt relief from the IMF would cover that portion of the successor arrangements under the PRGF and EFF corresponding to the stock of arrears at arrears clearance ${ }^{28}$ that was not already reduced by the HIPC Initiative debt relief. MDRI debt relief from IDA would cover all outstanding debt disbursed before end-2003 and still outstanding at the beginning of the quarter following confirmation of the country's eligibility by IDA's Executive Board (which would amount to the full cancellation of all remaining World Bank Group claims on Liberia). MDRI relief from AfDF would cover all such outstanding debt disbursed before end-2004 and still outstanding at the completion point (which, except for remaining Nigeria Trust Fund claims, would effectively cancel all remaining AfDB Group claims on Liberia).

60. Assuming that Liberia reaches the completion point in the last quarter of 2010, preliminary estimates indicate that the MDRI and MDRI-type beyond-HIPC debt relief could amount to US\$218.3 million in nominal terms (US\$132.5 million in NPV terms). Of this amount, US\$67.2 million would be provided by IDA, US $\$ 17.8$ by the AfDF, and US $\$ 133.3$ by the IMF. ${ }^{29}$ This compares with possible nominal HIPC Initiative assistance of US\$4,208.6 million (US\$2,994.7 million in NPV terms).

\footnotetext{
${ }^{28}$ These arrears represent debt contracted prior to end-2004. The new PRGF credit (currently assumed at 30 percent of quota under the $12^{\text {th }}$ General Review) is not eligible for beyond-HIPC assistance.

${ }^{29}$ The US\$218.3 million reflect total nominal debt service savings. However, the MDRI is a debt stock operation on all debt outstanding (principal only) as of end-2004 (IMF and AfDB) and end-2003 (IDA) that is not covered by HIPC assistance. This is expected to amount to US\$108.4 million.
} 


\section{Box 2: Key Macroeconomic Assumptions Underlying the DRA}

Key medium- to long-term macroeconomic assumptions used in the baseline DRA scenario include:

Annual real GDP growth averages 5.7 percent a year over the projection period (2008-27). Growth is projected to be supported by private investment in mining and agriculture, public infrastructure, and broader-based private investment derived from improvements in security and the strengthening of institutions.

CPI inflation is projected to decelerate from 9 percent in 2006 to 5 percent in the medium term, in line with assumed international prices and the domestic monetary policy stance.

Fiscal policy aims to meet the government's spending priorities while limiting future borrowing. Central government revenue is expected to increase gradually from $143 / 4$ percent of GDP in FY2005/06 to about 26 percent of GDP in FY2012/13, remaining there over the rest of the projection period. Expenditure is expected to increase to over $30 \frac{1}{2}$ percent of GDP in the long run, with an increased share of pro-poor spending in overall outlays. After debt relief delivery and the adoption of a debt management strategy, Liberia is assumed to commence borrowing in FY2010/11. The central government overall deficit (including grants), to be financed by both domestic and external borrowing, before HIPC Initiative assistance, is projected to average 3 percent of GDP over the projection period.

Official loan financing (excluding the IMF) is assumed to be on concessional terms (a 10-year grace period, 40 years maturity, and 0.75 percent interest rate) over the projection period. The resulting grant element for new disbursements is estimated at about 50 percent.

External grants, which increasingly go through the budget, are expected to increase at a rate lower than nominal GDP growth, declining from 32 percent of GDP in 2007 to about 12 percent by 2027, as the overall political situation and per capita GDP improve.

The external current account deficit (excluding grants) is expected to narrow from 63 percent of GDP in FY2006/07 to about 22 percent in FY2026/27 on the strength of net exports. FDI is projected to rise from 1 percent of GDP in 2006 to about 9 percent in 2007 (related to a significant investment in mining), and then to an average of 26 percent of GDP during 2008-10 (related to investment in agriculture and mining), gradually stabilizing at about 9 percent of GDP for the remainder of the projection period. The net liquid foreign assets of the CBL are expected to increase from under a month of imports of goods and services in 2007 to nearly three and a half months in 2027.

\section{Pending Liberia's successful implementation of the HIPC Initiative process, some Paris Club creditors are expected to provide further relief and cancel 100 percent} of their claims against Liberia after it reaches the completion point (see Table A10). This additional assistance would amount to US\$21.8 million in nominal terms (US\$15.2 million in NPV terms). 
62. Additional multilateral debt relief from IDA and the AfDB, beyond HIPC, during the interim period is described above. It is expected to take the form of grant financing to offset the costs of interim period debt servicing by Liberia to these institutions.

63. The delivery of MDRI and MDRI-type assistance and additional multilateral and bilateral debt relief beyond HIPC would further reduce Liberia's external debt. After the completion point, Liberia's NPV of debt-to-exports ratio would significantly fall, remaining below 20 percent over the projection period (through 2026/27). ${ }^{30}$ Compared to a projection including only HIPC assistance, this represents a reduction of about 25 percentage points at completion point (Table A6 and Figure 2).

\section{G. Sensitivity Analysis}

\section{Simulations under five scenarios were conducted to test the sustainability of} Liberia's external debt after HIPC Initiative assistance (Table A7 and Figure 2). Liberia's external debt situation would deteriorate under each scenario and the debt indicators would breach the HIPC threshold in the scenarios with a substitution of loans for grants and with a combination of shocks under the first four scenarios.

- The first scenario highlights the sensitivity of debt indicators to the concessionality of new borrowing. In contrast to the baseline scenario, new borrowing starting in FY2010/11 and remaining in place throughout the projection period is contracted with an assumed 200-basis-point increase in the interest rate paid. Exports receipts are assumed to be unchanged from the baseline scenario. Under this scenario, Liberia's NPV of debt-to-exports ratio slowly deteriorates relative to the baseline scenario, and gradually converges to about 25 percent in FY2026/27.

- The second scenario considers the sensitivity of the projections to lower export prices (25 percent lower than in the baseline). Under this scenario, the average growth rate of exports falls by about $1 \frac{1}{2}$ percentage points relative to the baseline (from 13.3 percent to 11.8 percent), and the NPV of debt to exports, assuming full delivery of HIPC Initiative assistance, declines until FY2012/13, reaching 64 percent. The NPV of debt to exports then gradually increases, reaching 119 percent by FY2026/27 (Table A7). Compared with the baseline scenario, this represents a deterioration of approximately 29 percentage points in FY2007/08, increasing to about 101 percentage points by FY2026/27.

- The third scenario considers the sensitivity of the projections to lower GDP growth. In this scenario, GDP is assumed to grow by 2.0 percentage points less than in the baseline (baseline assumes average growth of 8.1 percent FY2006/07-FY2016/17 and 4.0 percent in FY2017/18-FY2026/27) because of slower than expected progress in

\footnotetext{
${ }^{30}$ This assumes that the MDRI has no impact on Liberia's new borrowing over the projection period.
} 
enhancing security, strengthening governance and the rule of law, and rehabilitating infrastructure and basic services. The lower growth in turn would hurt government revenues and increase the need for new borrowing. Based on these assumptions, the NPV of debt to exports, assuming full delivery of HIPC Initiative assistance, would decline until FY2012/13, reaching 39 percent. The NPV of debt to exports would then gradually increase to about 113 percent in FY2026/27. Compared with the baseline, the debt-to-exports ratio would be about 4 percentage points higher in FY2007/08 and 95 percentage points higher by FY2026/27.

- The fourth scenario considers the sensitivity of the projections to a substitution of loans for the grants in the baseline assumed to finance projects outside the budget (about 80 percent of total grants). Under this assumption, the NPV of debt-to-exports ratio, after assuming full delivery of HIPC Initiative assistance, would decline until FY2012/13, reaching 58 percent; the NPV of debt-to-exports would then gradually increase to about 146 percent by FY2026/27. Compared with the baseline scenario, this represents an increase of 128 percentage points by FY2026/27. These results show the importance of external grant assistance to Liberia's economic and social recovery, and the adverse impact that additional borrowing to support them could have on debt sustainability.

- The fifth scenario considers the sensitivity of the projections to a combination of shocks under the preceding four scenarios. Under this assumption, the NPV of debt to exports, assuming full delivery of HIPC Initiative assistance, would be above 150 percent immediately after the occurrence of the shocks in FY2007/08, reaching 180 percent. The NPV of debt to exports would then continue to increase to about 647 percent in FY2026/27. Compared with the baseline, debt to exports would be about 39 percentage points higher in FY2007/08 and 629 percentage points higher by FY2026/27.

65. The sensitivity analysis indicates that Liberia's ability to service its external debt after HIPC relief is particularly vulnerable to the use of borrowing to compensate for possible limited external grant assistance, the external environment, as well as the continued implementation of the reform agenda. ${ }^{31}$ The achievement of a robust external debt position will also depend on real GDP growth and export performance. The analysis stresses the importance of strong and sustained efforts by the government and donors to (i) enhance national security; (ii) provide a conducive environment for private investment, particularly by strengthening governance and the rule of law and rehabilitating infrastructure and basic services; and (iii) design and implement a prudent debt management strategy which

\footnotetext{
${ }^{31}$ However, the baseline and the sensitivity analysis scenarios do not consider the impact of MDRI debt relief or additional bilateral assistance. A more detailed analysis will be included in the decision point document.
} 
recognizes that external assistance needs to be largely in the form of grants. The importance of a debt management strategy is reflected in the completion point triggers, discussed below.

\section{The Decision And Floating Completion Points}

\section{A. Possible Decision Point Timing}

66. Although some uncertainty remains, Liberia is expected to clear its arrears to the IMF and reach the HIPC decision point by end-February 2008. This is possible since (i) arrears to the World Bank Group and the African Development Bank Group were cleared in December 2007, (ii) sufficient financing pledges from member countries to allow the IMF to provide debt relief to Liberia were secured in November 2007, (iii) a strategy to clear arrears with other multilateral creditors is expected to be agreed by the date of the HIPC decision point, and (iv) a modification of the PRGF-HIPC Trust Instrument approved by the IMF Board in January 2008 allows Liberia's performance under the SMP to count as a track record for the HIPC decision point.

\section{B. Possible Triggers for the Floating Completion Point}

67. As outlined in Sections II and III, a program of key economic, governance, and structural reforms would support the peace and development of Liberia. The I-PRSP provides a framework for discussion of possible floating completion point triggers. The IDA and IMF staffs and the authorities have reached preliminary understandings on the major areas to be covered by triggers (see Box 3). Besides the standard triggers regarding the preparation and implementation of the full PRSP and the maintenance of macroeconomic stability, the triggers would focus on PFM, governance and debt management. Revised proposed triggers will be presented for Board consideration in the decision point document. It is expected that, if the country maintains macroeconomic stability and makes good progress on its PRSP, all triggers could be achieved within three years of the HIPC decision point.

\section{Monitoring Public Spending Following Provision of HIPC Assistance}

68. Securing the effective use of public spending for pro-poor growth is a key objective of the HIPC Initiative. The actual cash flow benefits of HIPC relief for Liberia will initially be extremely small. With the exception of small token payments to the IMF (US\$60,000 per month) and the AfDB (US\$15,000 per month), and goodwill payments to the World Bank (US\$25,000 per month, held in an escrow account and to be used for the benefit of Liberia), the government has not been servicing external debts to any of its creditors. Nevertheless, debt relief under the HIPC Initiative and MDRI-type assistance must be 


\section{Box 3: Possible Triggers for Liberia's Floating Completion Point}

\section{PRSP}

- Prepare a full PRSP through a participatory process and implement satisfactorily its recommended actions for at least one year, as evidenced by an Annual Progress Report submitted by the government to the staffs of IDA and the IMF

\section{Macroeconomic stability}

- Maintain macroeconomic stability, as evidenced by satisfactory performance under a PRGF/EFF-supported program

\section{Public financial management}

- Quarterly Publication in the Procurement bulletin and monthly publication in the Website of all signed procurement contracts over US $\$ 25,000$ for goods, US $\$ 10,000$ for consulting services, and US $\$ 50,000$ for works and all signed-sole source procurement and concessions contracts which have been identified by the PPCC as a result of the PPCC's compliance monitoring activities for at least 6 months leading up to the completion point

- Complete successive annual external audits of five key government ministries (Health, Education, Public Works, Finance and Lands, Mines and Energy), prepared under the authority of the General Auditing Commission, submitted to the legislature and disclosed publicly

- Implement the new PFM law and supporting financial regulations for at least 12 months leading up to the completion point

- Ensure that the Basic Package of Health Services is delivered in at least 40 percent of all health facilities nationwide

- Complete a harmonized and regularized Ministry of Education payroll

\section{Debt Management}

- Develop a debt management strategy in consultation with partners and establish a debt management unit recording all information on external and domestic public and publicly guaranteed debt, including for state owned enterprises

- Publish, on a quarterly basis and on a government website, data on external and domestic public and publicly guaranteed debt, including debt stocks and terms and conditions of new loan agreements for at least 6 months leading up to the completion point

\section{Governance}

- Implement a revised investment incentive code to ban granting tax exemptions outside the Liberia Revenue Code

- Become an EITI-compliant country, including by (i) establishing and maintaining regular public reporting of payments to, and revenues received by, the government during at least the 6 month period leading up to the completion point; and (ii) actively engaging civil society in the design, monitoring and evaluation of this process, including publication of at least one civil society-led monitoring report based on extractive industries and forestry concessions operating in Liberia at that time

- Establish an independent Anti-Corruption Commission consistent with the Anti-Corruption Act, and ensure it is operational for at least 12 months leading up to the completion point 
accompanied by a strong program that ensures the effective use of domestic and external resources and reflects the expenditure priorities in the government's poverty reduction strategy. This will require continued efforts to strengthen the programming, management, control and monitoring of expenditures, and improved service delivery in key sectors. It will also require costing PRSP priorities and developing a medium-term expenditure framework to efficiently allocate public resources for meeting PRSP objectives.

\section{With IMF and World Bank technical assistance and other support under} GEMAP, major steps have been taken to improve PFM. The interim commitment control system successfully prevented new domestic arrears and ensures that commitment vouchers are reviewed by the CMCo. An international expert maintains co-signing authority for the $\mathrm{CMCo}$, and coordinates with the international chief administrator on the monitoring of the government's account at the CBL. ${ }^{32}$ Under the GEMAP, international controllers have similar authority at the major revenue-generating SOEs and the Ministry of Lands, Mines and Energy; and under a memorandum of understanding, SOE revenues flow through a special account for each SOE at a single commercial bank, where they may be monitored. Progress has also been made in strengthening the budget preparation process and on improving fiscal reporting.

\section{Notwithstanding the progress to date, further efforts are needed to improve}

PFM. Budget preparation, implementation, and cash management need enhancing; revenues also need to be increased further.

71. Liberia is receiving substantial technical assistance to help strengthen its PFM. The World Bank, IMF, and AfDB provide technical assistance and training in PFM to the Ministry of Finance, and the U.S. Government to the Bureau of the Budget; the government intends to merge the Bureau into the Ministry of Finance. The IMF provides financing to support the special advisor at the CBL and technical assistance in revenue mobilization to the Ministry of Finance. The United States has assisted in the introduction of a computerized payment system with full accountability checks at each stage. The World Bank is providing capacity building and training support to ministries and agencies to improve compliance with public procurement legal requirements. However, enduring gains in transparency, financial management systems, and accountability will require Liberia's international partners to sustain their support of the government's reform process.

\section{The government is developing a medium-term PFM reform strategy with support from the IMF's Fiscal Affairs Department (FAD), as part of a broader PEMFAR being lead by the World Bank and the IMF. ${ }^{33}$ The PEMFAR will help assess}

\footnotetext{
32 The IMF-supported chief administrator, who assumed his position in February 2006, resigned in midSeptember 2007. The IMF is currently recruiting a successor for this position - the title of which will be redesignated special advisor.

${ }^{33}$ An FAD technical assistance mission to discuss PFM reforms took place in October 2007.
} 
fiduciary risks associated with budget support, identify areas for a prioritized action plan, and deepen the dialogue between Liberia and its partners on PFM. The content of the PEMFAR includes a Country Financial Accountability Assessment (CFAA), a Country Procurement Assessment Review (CPAR), an assessment of the systems and arrangements for budget planning, and a PFM reform strategy that includes an action plan for reforms to be implemented over the short, medium, and long term. The PEMFAR findings will be used to compile a set of standard PEFA ratings covering as many of the 31 PEFA performance assessment indicators as possible, creating a benchmark for future PFM reforms. ${ }^{34}$

\section{A basic monitoring mechanism for tracking expenditures is being implemented.}

The government will track expenditure manually, or using existing systems, until the Integrated Financial Management Information System (IFMIS), which is being developed according to the needs of the Ministry of Finance, is designed and installed. Until then, certain budget codes will be designated as PRSP priority expenditures so that the existing system for expenditure authorizations can track such spending.

\section{The government intends to use these systems to track its total budget outlays} against its medium-term expenditure priorities, as defined by its I-PRSP and successor PRSP. Possible medium-term expenditure priorities are in Box 4. These benchmarks, however, are indicative only, and will be elaborated in consultation with the government as it develops its PRSP and expenditure plans.

\footnotetext{
${ }^{34}$ Liberia's SMP contains end-March 2008 benchmarks consistent with recommendations of the FAD mission on PFM reform, including (i) passage of legislation to allow the merger of the Bureau of the Budget into the Finance Ministry and to limit the transfer of resources between budget lines without legislative approval; and (ii) preparing a chart of accounts, consistent with GFSM 2001-compatible budgetary classifications. If a PRGF/EFF-supported program is approved before end-March 2008, these measures would be monitored under the new program.
} 


\section{Box 4: Possible Medium-Term Expenditure Priorities}

Expenditure priorities identified in the government's I-PRSP include the following:

- $\quad$ Education: Rehabilitation of 80 percent of damaged primary and secondary schools; rehabilitation of three teacher training institutions; school feeding programs introduced; and training facility for artisans and craftsmen opened.

- $\quad$ Health: Improving 354 existing health facilities and provisioning the basic health services in 70 percent of health facilities; renovating and staffing three county hospitals; operating four facilities for youth offenders and four facilities for people with disabilities; preparing long-term health development plans specific to each county; creating a National AIDS commission and strengthening welfare institutions to assist vulnerable groups; rehabilitating nine potable water facilities; and operating a new waste disposal system.

- $\quad$ Agricultural Development: preparing a national food security policy; providing seeds and tools to smallholders through regional seed centers; rehabilitating 1,000 hectares and 100 abandoned fish ponds; assisting 2,000 coastal fishers; providing 1,000 shortcycle ruminants; revitalizing the tree crops subsector; increase investment in commercial plantations; identifying impediments to private sector participation in agriculture and endorse appropriate incentives; reactivate extension services; and restructure agricultural marketing credit and input supply through the private sector.

- $\quad$ Public Works: Rebuilding 109 miles of roads, 300 miles of feeder roads, and 25 miles of urban roads; renovation of the road maintenance and training center; and restoration of Roberts International Airport to international standards.

\section{ISSUES FOR DISCUSSION}

\section{This paper assesses Liberia's eligibility for assistance under the Enhanced HIPC Initiative. Executive Directors' views and guidance are sought on the following issues:}

- Eligibility: Do Directors agree that Liberia is eligible for assistance under the HIPC Initiative?

- Timing of the decision point: Do Directors agree with the staffs' recommendation that Liberia could reach its decision point by end-February 2008, together with the approval of a PRGF arrangement by the IMF Board, provided that (i) Liberia has a current sixmonth track record of satisfactory performance under a program of upper-credit tranche policy conditionality with the IMF; (ii) Liberia clears its arrears to its multilateral creditors or agrees on a strategy to clear them; and (iii) Liberia agrees on appropriate completion point triggers? 
- Floating completion point: What are Directors' views on staffs' recommendations on possible triggers against which satisfactory performance would be measured for the floating completion point (Box 3)? 
Figure 1A. Republic of Liberia: Composition of Stock of External Debt at End-June 2007 by Creditor Group

(Nominal stock: \$4,788.4 million)

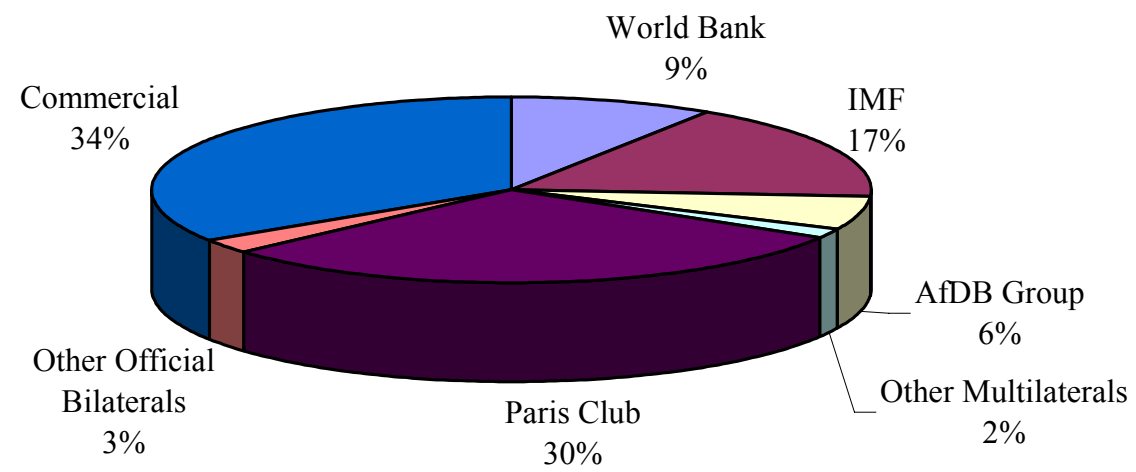

Figure 1B. Republic of Liberia: Potential Costs of the HIPC Initiative by Creditor Group

(Total Estimated Enhanced HIPC Assistance: \$2,994.7 million, end-June 2007 NPV terms)

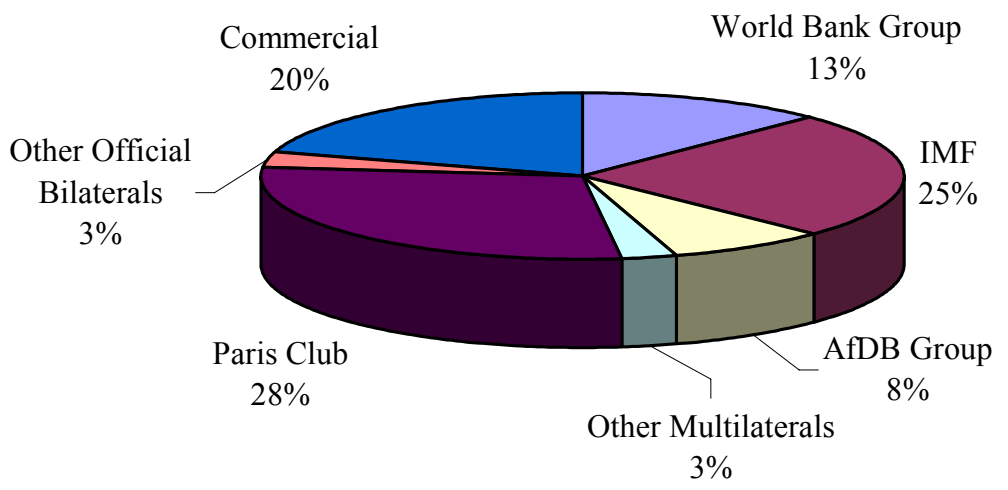

Sources: Liberian authorities and staff estimates. 
Figure 2. Republic of Liberia: External Debt

Sustainability Indicators, 2006/07-2026/27

\section{NPV of Debt-to-Exports \\ (Percent of Exports)}

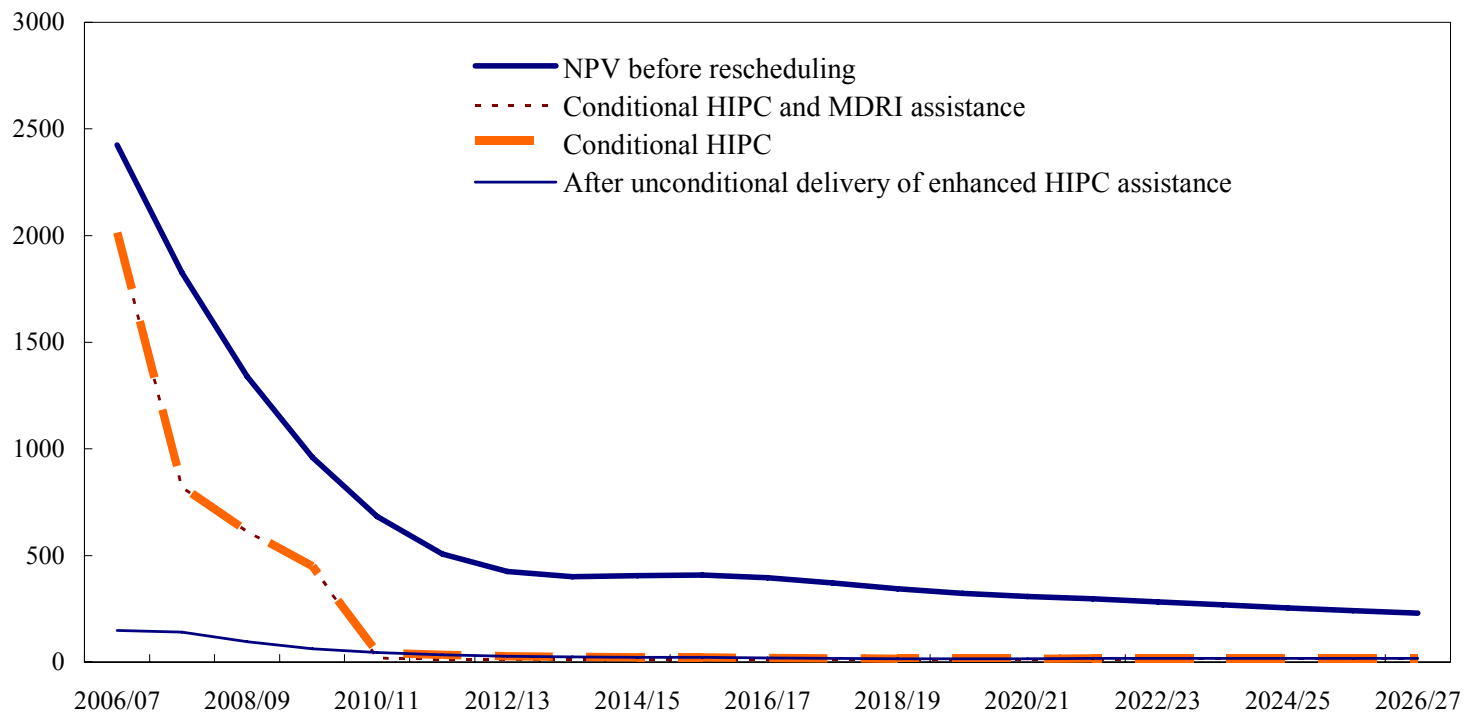

Debt Service-to-Exports

(Percent of Exports)

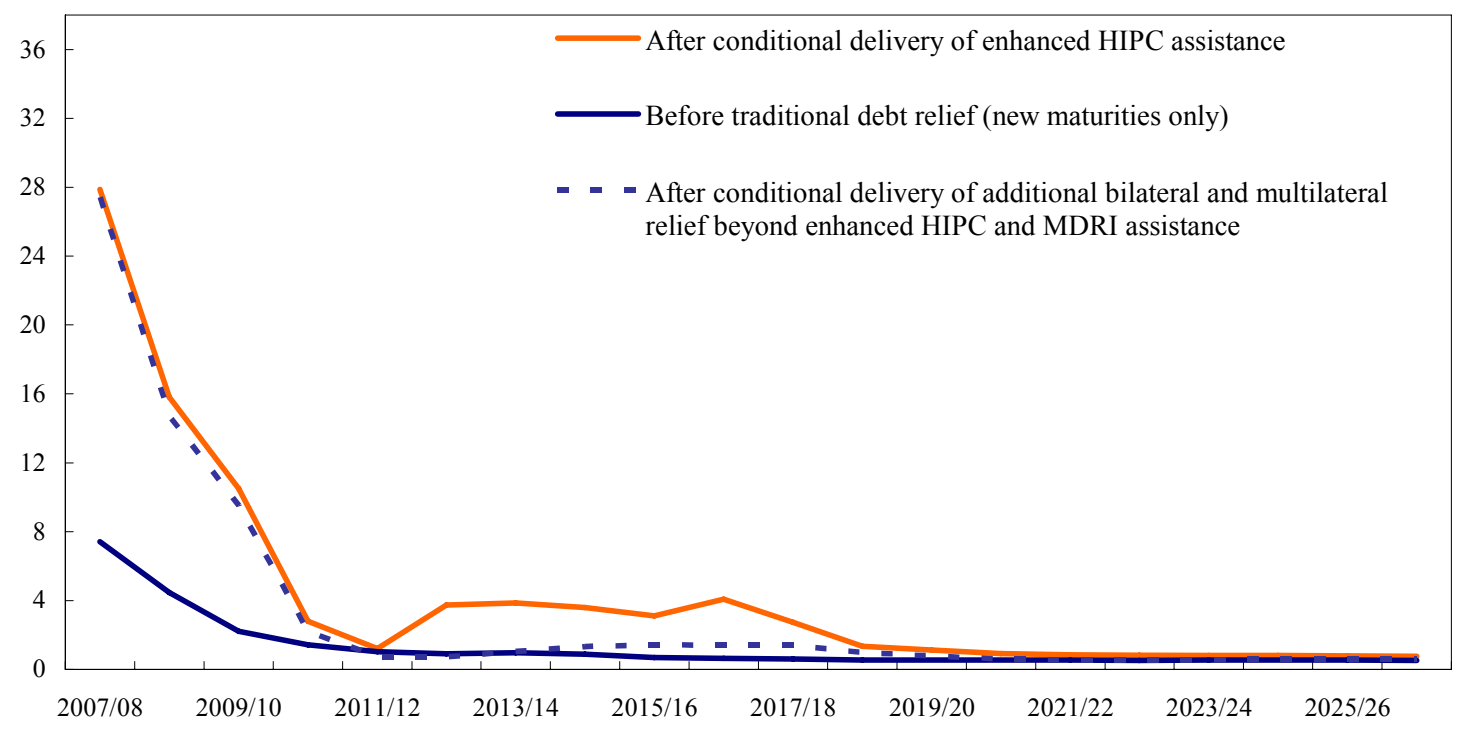

Sources: Liberian authorities and staff estimates and projections. 
Figure 3. Republic of Liberia: Sensitivity Analysis, 2006/07-2026/27

\section{NPV of Debt-to-Exports \\ (Percent of Exports)}

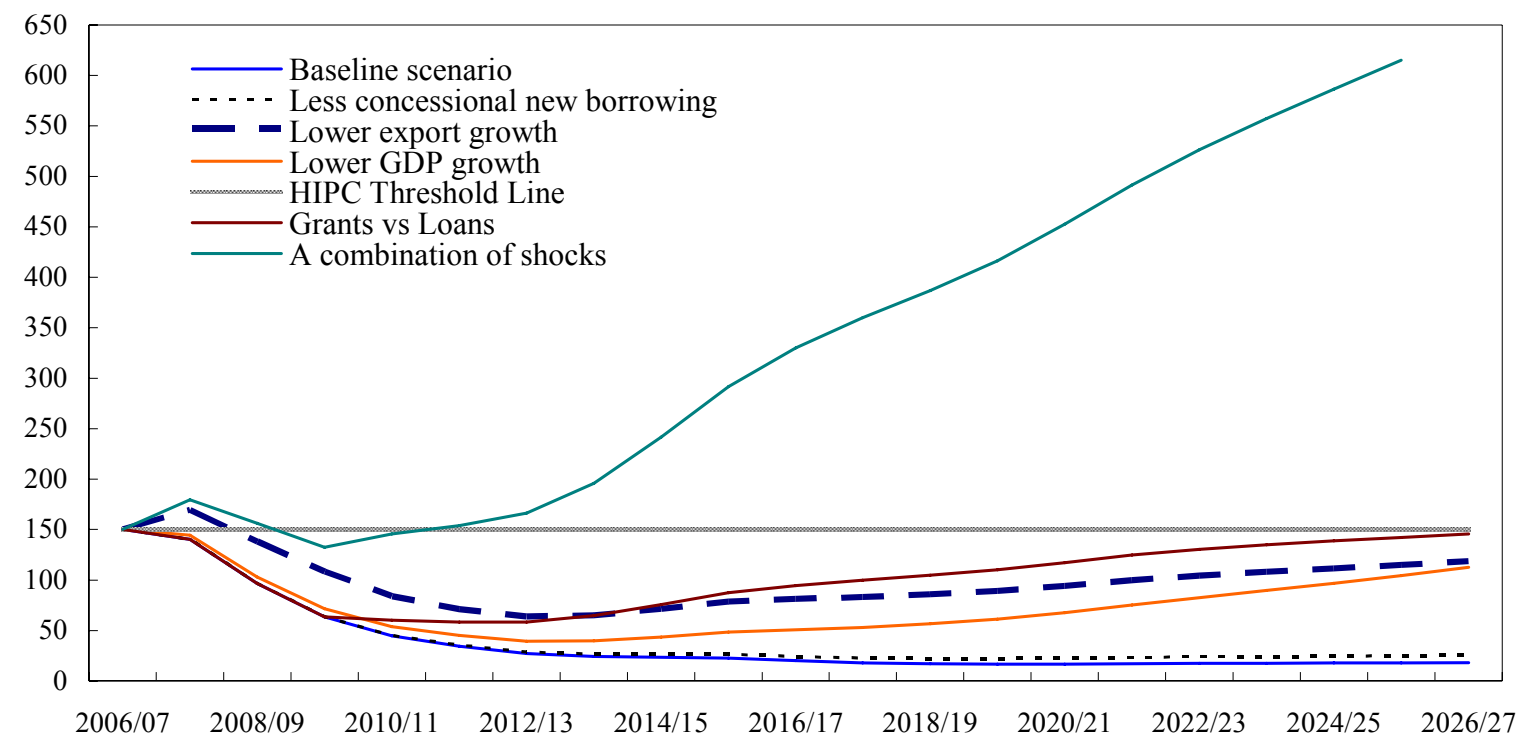

Debt Service-to-Exports

(Percent of Exports)

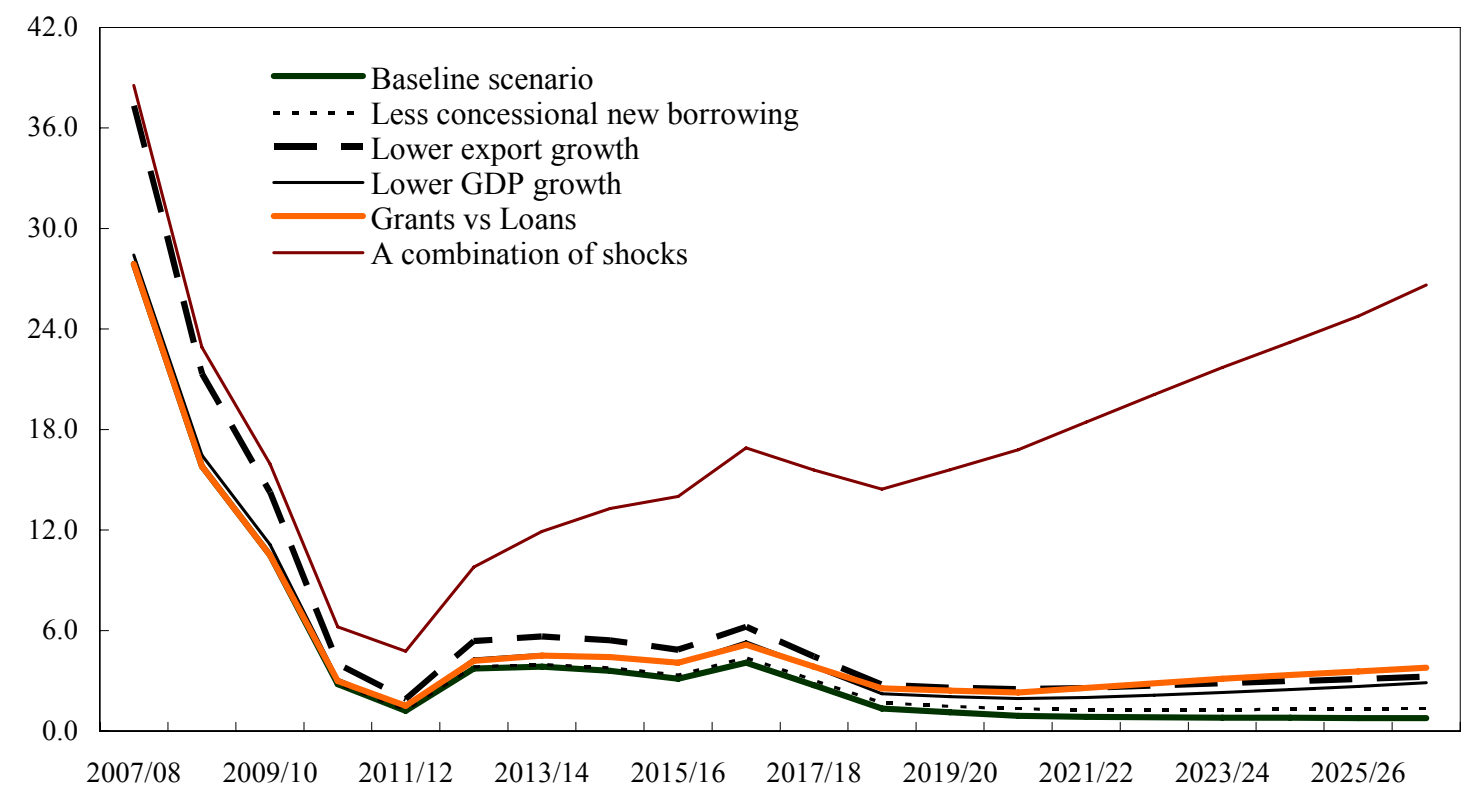

Sources: Liberian authorities and staff estimates and projections. 
Table A1. Republic of Liberia: Nominal Stock and Net Present Value of Debt at end-June 2007 by Creditor Group 1/ (Millions of US\$, unless otherwise specified)

\begin{tabular}{|c|c|c|c|c|c|c|c|c|}
\hline & \multicolumn{2}{|c|}{ Nominal Debt Stock } & \multicolumn{2}{|c|}{ Arrears } & \multicolumn{2}{|c|}{ NPV of Debt 2/ } & \multicolumn{2}{|c|}{$\begin{array}{c}\text { NPV of Debt After } \\
\text { Traditional Debt Relief 3/ }\end{array}$} \\
\hline & $\begin{array}{c}\text { Nominal } \\
\text { value }\end{array}$ & $\begin{array}{l}\text { Percent } \\
\text { of total }\end{array}$ & $\begin{array}{c}\text { Nominal } \\
\text { value }\end{array}$ & $\begin{array}{l}\text { Percent } \\
\text { of total }\end{array}$ & $\begin{array}{l}\mathrm{NPV} \\
\text { terms }\end{array}$ & $\begin{array}{l}\text { Percent } \\
\text { of total }\end{array}$ & $\begin{array}{l}\text { NPV } \\
\text { terms }\end{array}$ & $\begin{array}{l}\text { Percent } \\
\text { of total }\end{array}$ \\
\hline Total & $4,788.4$ & 100.0 & $4,601.4$ & 100.0 & $4,739.3$ & 100.0 & $3,288.0$ & 100.0 \\
\hline Multilateral & $1,614.8$ & 33.7 & $1,499.3$ & 32.6 & $1,575.8$ & 33.2 & $1,575.8$ & 47.9 \\
\hline World Bank & 442.6 & 9.2 & 366.9 & 8.0 & 414.6 & 8.7 & 414.6 & 12.6 \\
\hline IMF & 809.2 & 16.9 & 809.2 & 17.6 & 809.2 & 17.1 & 809.2 & 24.6 \\
\hline AfDB Group & 271.3 & 5.7 & 240.2 & 5.2 & 263.1 & 5.6 & 263.1 & 8.0 \\
\hline OFID & 23.7 & 0.5 & 23.7 & 0.5 & 23.7 & 0.5 & 23.7 & 0.7 \\
\hline IFAD & 22.1 & 0.5 & 18.4 & 0.4 & 20.8 & 0.4 & 20.8 & 0.6 \\
\hline BADEA & 19.1 & 0.4 & 19.1 & 0.4 & 19.1 & 0.4 & 19.1 & 0.6 \\
\hline $\mathrm{EU}$ & 9.4 & 0.2 & 4.4 & 0.1 & 7.9 & 0.2 & 7.9 & 0.2 \\
\hline EIB & 12.3 & 0.3 & 12.3 & 0.3 & 12.3 & 0.3 & 12.3 & 0.4 \\
\hline ECOWAS & 5.0 & 0.1 & 5.0 & 0.1 & 5.0 & 0.1 & 5.0 & 0.2 \\
\hline Bilateral and commercial & $3,173.6$ & 66.3 & $3,102.1$ & 67.4 & $3,163.6$ & 66.8 & $1,712.3$ & 52.1 \\
\hline Paris Club 4/ & $1,413.8$ & 29.5 & $1,353.5$ & 29.4 & $1,406.2$ & 29.7 & 948.7 & 28.9 \\
\hline Post-cutoff date & 431.5 & 9.0 & 403.5 & 8.8 & 427.2 & 9.0 & 423.3 & 12.9 \\
\hline ODA & 134.0 & 2.8 & 106.1 & 2.3 & 129.8 & 2.7 & 128.7 & 3.9 \\
\hline Non-ODA & 297.5 & 6.2 & 297.5 & 6.5 & 297.5 & 6.3 & 294.6 & 9.0 \\
\hline Pre-cutoff date & 982.4 & 20.5 & 949.9 & 20.6 & 979.0 & 20.7 & 525.4 & 16.0 \\
\hline ODA & 622.7 & 13.0 & 590.3 & 12.8 & 619.3 & 13.1 & 406.5 & 12.4 \\
\hline Non-ODA & 359.7 & 7.5 & 359.7 & 7.8 & 359.7 & 7.6 & 118.8 & 3.6 \\
\hline Belgium & 35.8 & 0.7 & 34.7 & 0.8 & 35.6 & 0.8 & 35.3 & 1.1 \\
\hline Denmark & 29.4 & 0.6 & 25.6 & 0.6 & 29.1 & 0.6 & 28.9 & 0.9 \\
\hline EEC IDA Administered & 2.1 & 0.0 & 0.9 & 0.0 & 1.7 & 0.0 & 0.6 & 0.0 \\
\hline Finland & 2.7 & 0.1 & 2.7 & 0.1 & 2.7 & 0.1 & 1.4 & 0.0 \\
\hline France & 156.6 & 3.3 & 156.6 & 3.4 & 156.6 & 3.3 & 152.7 & 4.6 \\
\hline Germany & 410.4 & 8.6 & 397.3 & 8.6 & 409.4 & 8.6 & 216.8 & 6.6 \\
\hline Italy & 67.7 & 1.4 & 67.7 & 1.5 & 67.7 & 1.4 & 58.0 & 1.8 \\
\hline Japan & 125.4 & 2.6 & 125.4 & 2.7 & 125.4 & 2.6 & 124.8 & 3.8 \\
\hline Netherlands & 35.0 & 0.7 & 35.0 & 0.8 & 35.0 & 0.7 & 33.9 & 1.0 \\
\hline Norway & 42.3 & 0.9 & 42.3 & 0.9 & 42.3 & 0.9 & 14.0 & 0.4 \\
\hline Sweden & 29.8 & 0.6 & 29.8 & 0.6 & 29.8 & 0.6 & 9.8 & 0.3 \\
\hline Switzerland & 2.5 & 0.1 & 2.5 & 0.1 & 2.5 & 0.1 & 2.5 & 0.1 \\
\hline United Kingdom & 49.1 & 1.0 & 49.1 & 1.1 & 49.1 & 1.0 & 16.2 & 0.5 \\
\hline United States & 425.0 & 8.9 & 383.8 & 8.3 & 419.2 & 8.8 & 253.7 & 7.7 \\
\hline Other official bilateral & 119.7 & 2.5 & 108.6 & 2.4 & 117.3 & 2.5 & 100.8 & 3.1 \\
\hline Post-cutoff date & 81.1 & 1.7 & 70.0 & 1.5 & 78.8 & 1.7 & 78.1 & 2.4 \\
\hline Pre-cutoff date & 38.5 & 0.8 & 38.5 & 0.8 & 38.5 & 0.8 & 22.7 & 0.7 \\
\hline ODA & 38.5 & 0.8 & 38.5 & 0.8 & 38.5 & 0.8 & 22.7 & 0.7 \\
\hline Non-ODA & 0.0 & 0.0 & 0.0 & 0.0 & 0.0 & 0.0 & 0.0 & 0.0 \\
\hline China & 6.1 & 0.1 & 1.1 & 0.0 & 3.9 & 0.1 & 3.9 & 0.1 \\
\hline Kuwait & 11.3 & 0.2 & 11.3 & 0.2 & 11.3 & 0.2 & 8.6 & 0.3 \\
\hline Saudi Arabia & 27.2 & 0.6 & 27.2 & 0.6 & 27.2 & 0.6 & 14.1 & 0.4 \\
\hline Taiwan, Province of China & 75.1 & 1.6 & 69.0 & 1.5 & 74.9 & 1.6 & 74.2 & 2.3 \\
\hline Commercial 5/ & $1,640.1$ & 34.3 & $1,640.1$ & 35.6 & $1,640.1$ & 34.6 & 662.8 & 20.2 \\
\hline Post-cutoff date & 183.0 & 3.8 & 183.0 & 4.0 & 183.0 & 3.9 & 181.2 & 5.5 \\
\hline Pre-cutoff date & $1,457.1$ & 30.4 & $1,457.1$ & 31.7 & $1,457.1$ & 30.7 & 481.6 & 14.6 \\
\hline \multicolumn{9}{|l|}{ Of which: } \\
\hline Suppliers credits & 383.5 & 8.0 & 383.5 & 8.3 & 383.5 & 8.1 & 191.3 & 5.8 \\
\hline
\end{tabular}

Sources: Liberian authorities and staff estimates.

1/ Liberia's fiscal year runs from July to June.

2/ Discount rates applied are the average commercial Interest Reference Rates published by the OECD over the 6 month period prior to June 2007

3/ Assumes a stock-of-debt operation on Naples terms at end-June 2007; and comparable action by other official bilateral creditors

on eligible debt (pre-cutoff and non-ODA).

4/ Paris Club cutoff date is January 1, 1983.

5/ Based on the estimated stock of debt provided by the government's financial advisor. 
Table A2. Republic of Liberia: HIPC Initiative-Assistance Under a Proportional Burden-Sharing Approach 1/ 2/

(Millions of U.S. dollars, unless otherwise indicated)

\begin{tabular}{|c|c|c|c|c|}
\hline $\begin{array}{l}\text { NPV of debt- } \\
\text { to-exports-target } \\
\text { (Percent) }\end{array}$ & Total & $\begin{array}{c}\text { Bilateral and } \\
\text { Commercial } \\
\text { (NPV terms at end-June 2007) }\end{array}$ & Multilateral & $\begin{array}{c}\text { Common Reduction } \\
\text { Factor 3/ } \\
\text { (Percent) }\end{array}$ \\
\hline 150 & $2,994.7$ & $1,559.5$ & $1,435.2$ & 91.08 \\
\hline \multicolumn{5}{|l|}{ Memorandum items: } \\
\hline NPV of debt & 3,288 & 1,712 & 1,576 & \\
\hline Paris Club creditors & 949 & & & \\
\hline Of which: pre-cutoff date non-ODA debt & 119 & & & \\
\hline Non-Paris Club creditors & 101 & & & \\
\hline Of which: pre-cutoff date non-ODA debt & 0 & & & \\
\hline Three-year average of exports & 196 & & & \\
\hline Current-year exports & 254 & & & \\
\hline NPV of debt-to-exports ratio 4/ & 1,681 & & & \\
\hline
\end{tabular}

Sources: Liberian authorities and staff estimates and projections.

1/ The proportional burden-sharing approach is described in "HIPC Initiative--Estimated Costs and Burden Sharing Approaches."

2/ Based on end-June 2007 data after full application of traditional debt relief mechanisms. Includes a hypothetical stock-of-debt operation on Naples terms and comparable treatment by other official bilateral creditors.

3/ Each creditor's HIPC relief in NPV terms in percent of its exposure at the decision point reference date. A common reduction factor of 91.08 percent is applied to debt remaining after traditional mechanisms. For non-concessional bilateral or commercial debts this would imply a total reduction of 97.03 percent.

4/ Based on the three-year export average (backward-looking average, i.e., 2004/05-2006/07).

Note: Exports of non-factor services are estimated using the methodology described in Annex II. 
Table A3. Republic of Liberia: Discount and Exchange Rate Assumptions at End-June 2007

\begin{tabular}{lcc}
\hline & Discount Rate 1/ & Exchange Rate 2/ \\
Currency Name & (Percent per annum) & (Currency per U.S. dollar) \\
\hline Canadian dollar & 5.01 & 0.9404 \\
CFA franc & 4.94 & 0.0021 \\
Chinese yuan & 5.07 & 0.1313 \\
Danish kroner & 4.96 & 0.1815 \\
Euro & 4.94 & 1.3505 \\
Great Britain sterling & 5.92 & 2.0049 \\
Italian lira & 4.94 & 0.0007 \\
Liberian dollar & 4.94 & 0.0160 \\
Japanese yen & 2.41 & 0.0081 \\
Kuwaiti dinar & 5.62 & 3.4715 \\
Norwegian kroner & 5.50 & 0.1695 \\
Saudi Arabia riyal & 5.07 & 0.2670 \\
Special drawing rights & 5.07 & 1.5156 \\
Swiss franc & 3.53 & 0.8153 \\
United States dollar & 5.62 & 1.0000 \\
& & \\
Memorandum item: & & \\
Paris Club cutoff date & & \\
& & \\
Sources: OECD; and IMF, International Financial Statistics. & & \\
\end{tabular}

1/ The discount rates used are the average Commercial Interest Reference Rates published by the OECD over the six-month period prior to June 2007.

2/ The exchange rates are expressed as national currency per U.S. dollar at end-June 2007. 


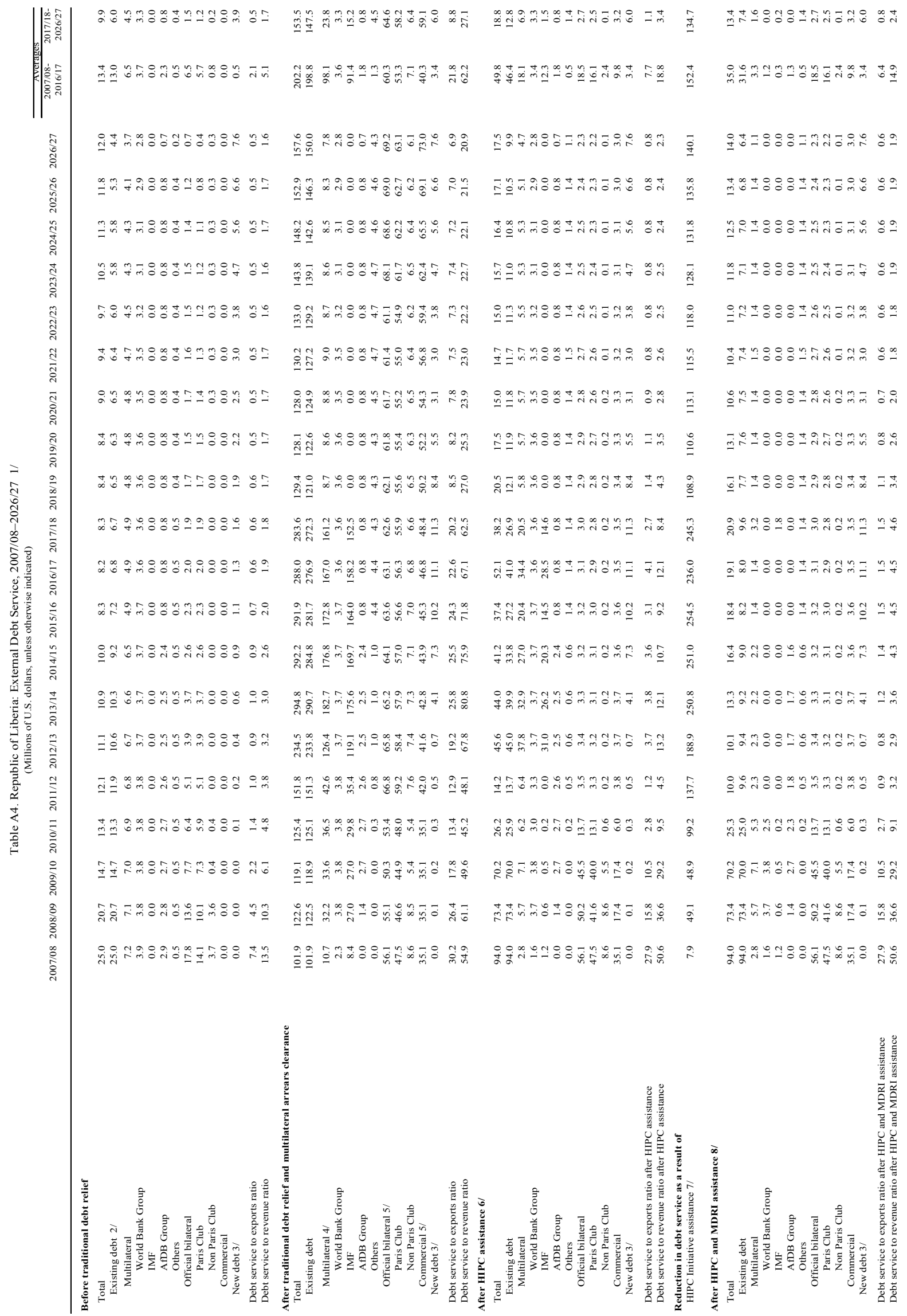




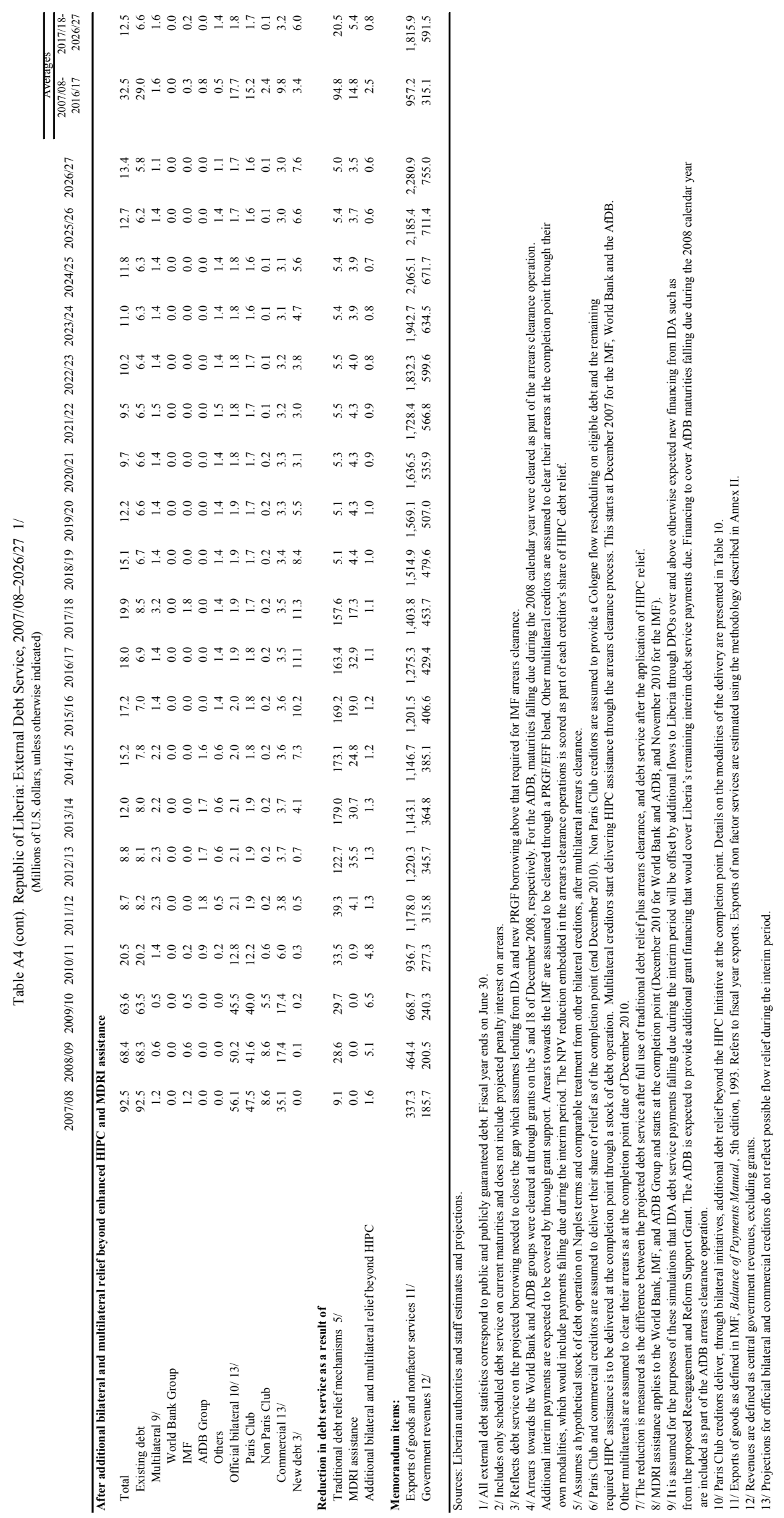




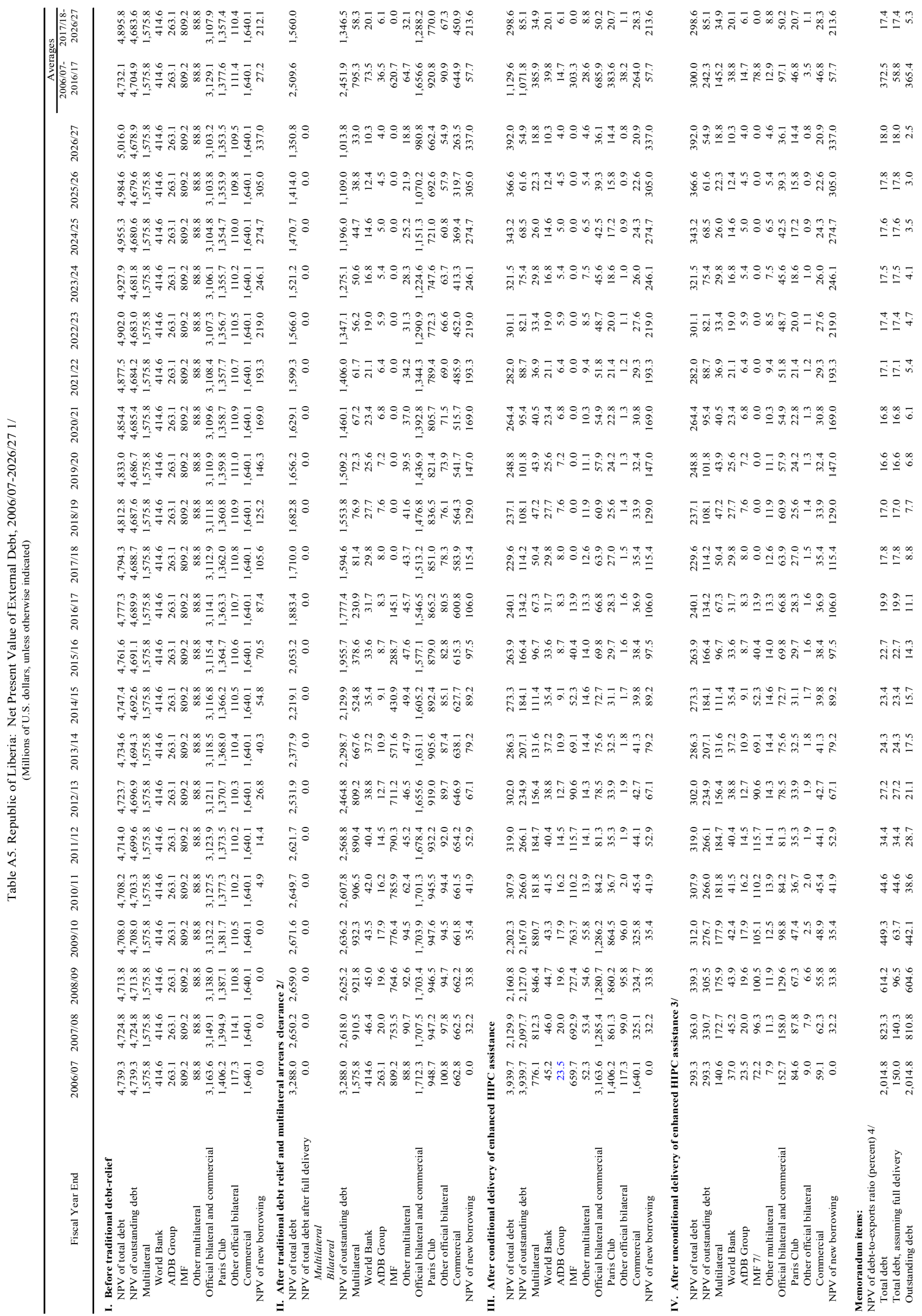




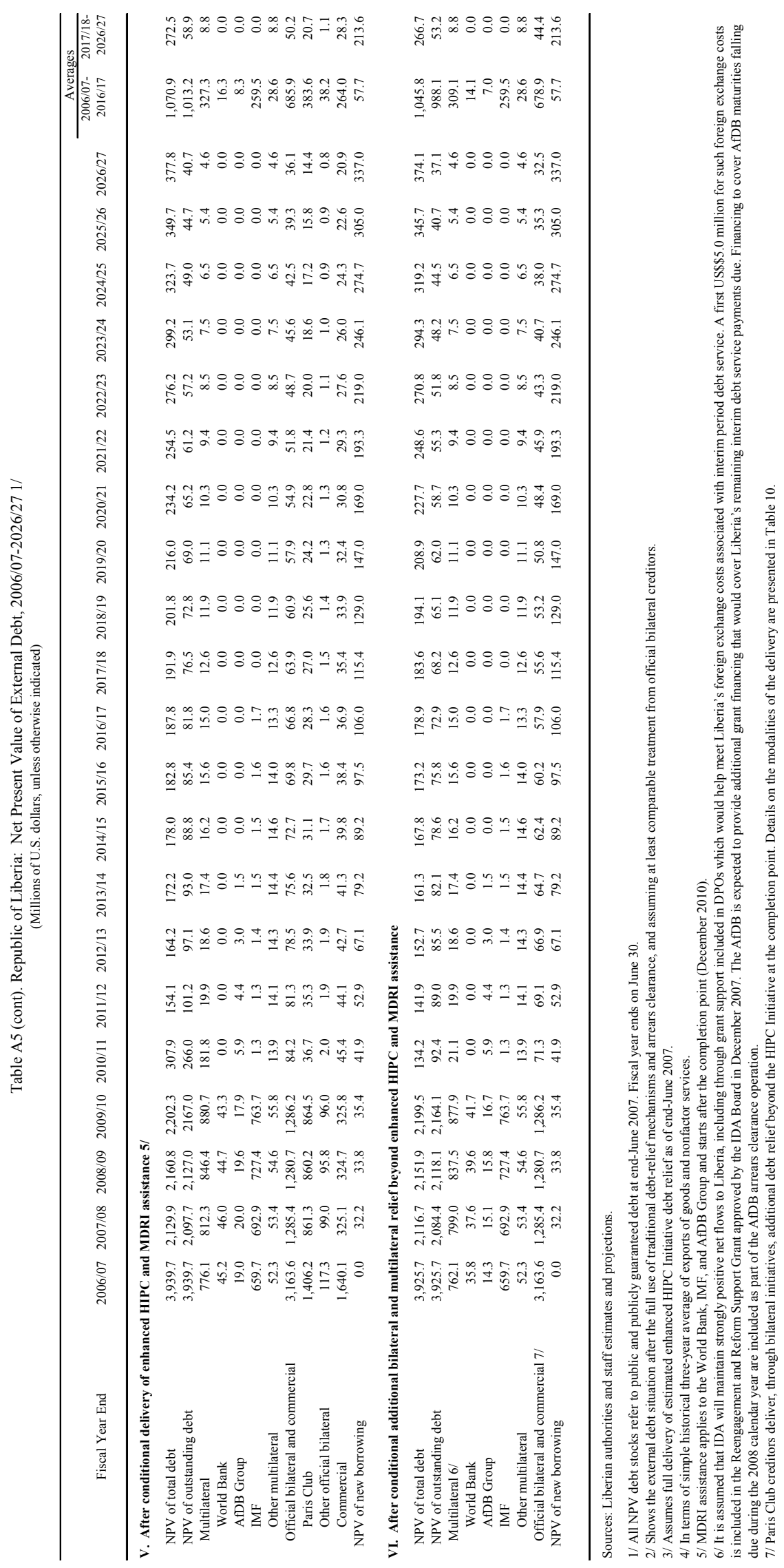




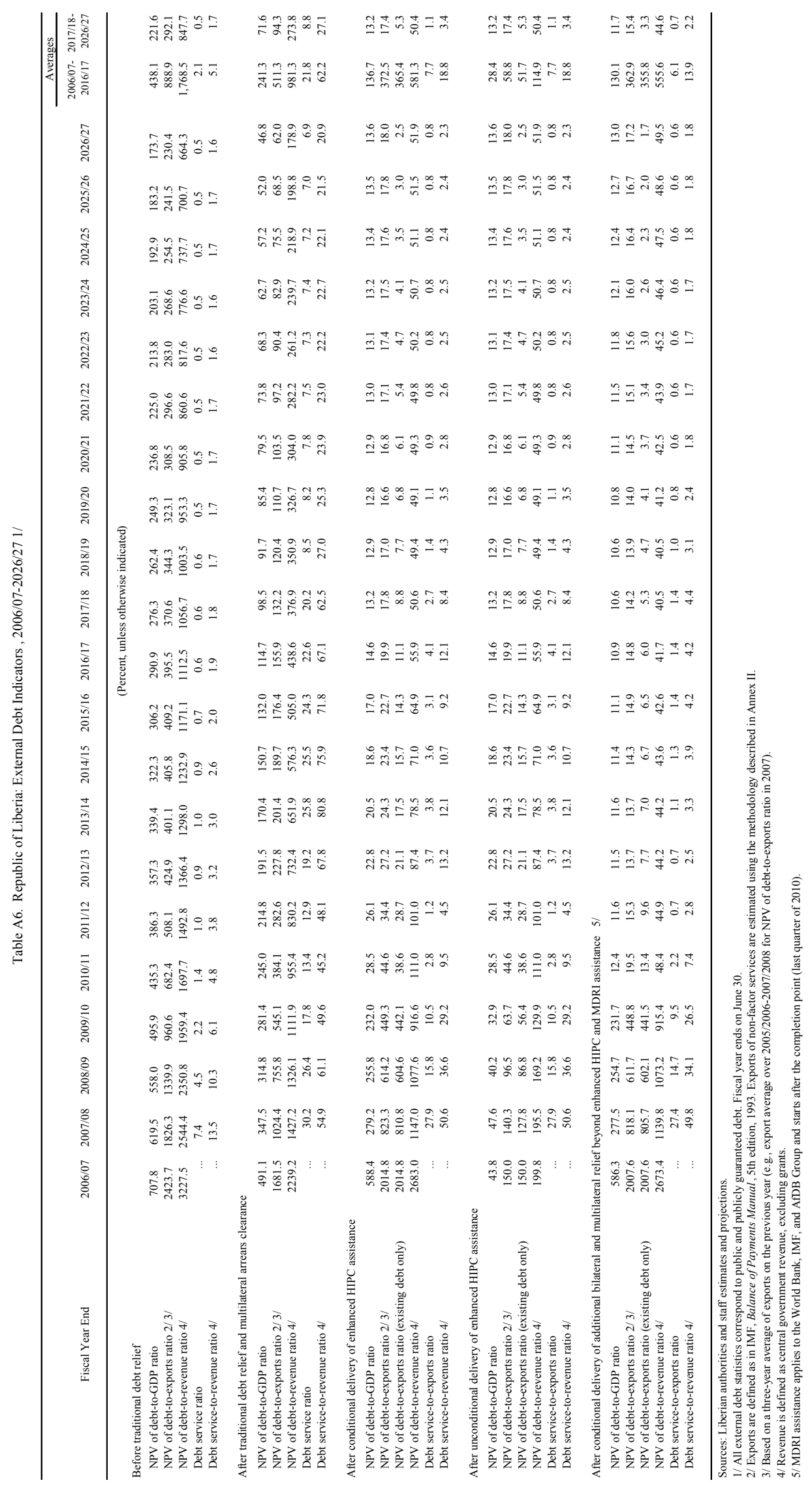




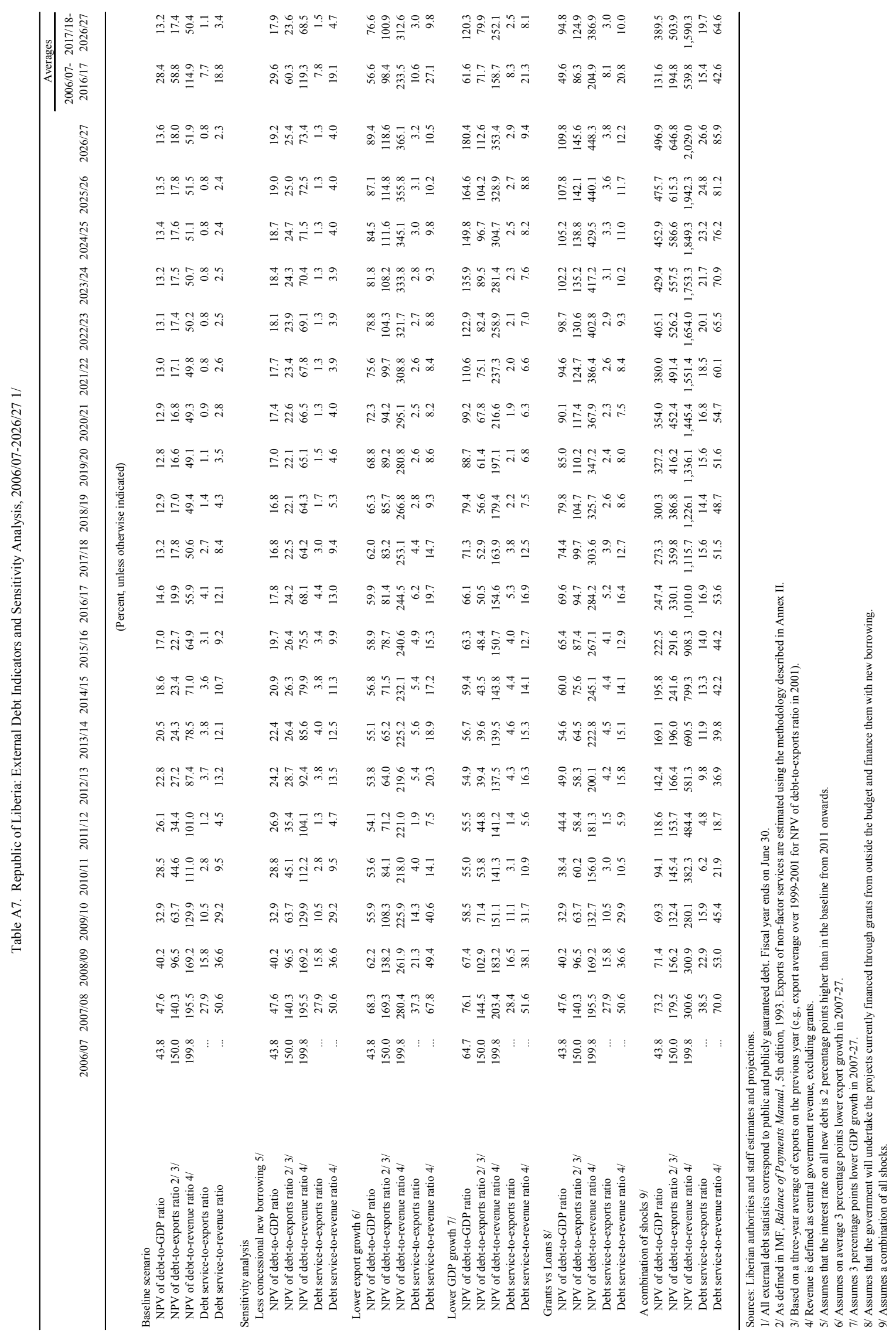


Table A8. HIPC Initiative: Status of Country Cases Considered Under the Initiative, December 20, 2007

\begin{tabular}{|c|c|c|c|c|c|c|c|c|c|c|c|}
\hline \multirow{3}{*}{ Country } & \multirow{3}{*}{$\begin{array}{r}\text { Decision } \\
\text { Point }\end{array}$} & \multirow{3}{*}{$\begin{array}{r}\text { Completion } \\
\text { Point }\end{array}$} & \multirow{3}{*}{\multicolumn{2}{|c|}{$\begin{array}{c}\text { Target } \\
\text { NPV of Debt-to- } \\
\begin{array}{r}\text { Gov. } \\
\text { Exports }\end{array} \frac{\text { revenue }}{\text { (in percent) }}\end{array}$}} & \multicolumn{5}{|c|}{$\begin{array}{c}\text { Assistance Levels 1/ } \\
\text { (In millions of U.S. dollars, present value) }\end{array}$} & \multirow{3}{*}{$\begin{array}{r}\text { Percentage } \\
\text { Reduction } \\
\text { in NPV of } \\
\text { Debt 2/ }\end{array}$} & \multirow{3}{*}{$\begin{array}{r}\text { Estimated Total } \\
\text { Nominal Debt } \\
\text { Service Relief } \\
\text { (In millions of } \\
\text { U.S. dollars) } \\
\end{array}$} \\
\hline & & & & & \multirow[b]{2}{*}{ Total } & \multirow{2}{*}{$\begin{array}{l}\text { Bilateral and } \\
\text { commercial } \\
\end{array}$} & \multicolumn{3}{|c|}{ Multilateral } & & \\
\hline & & & & & & & Total & IMF & World Bank & & \\
\hline \multicolumn{12}{|c|}{ Completion point reached under enhanced framework (22) } \\
\hline Benin & Jul. 00 & Mar. 03 & 150 & & 265 & 77 & 189 & 24 & 84 & 31 & 460 \\
\hline Bolivia & & & & & 1,302 & 425 & 876 & 84 & 194 & & 2,060 \\
\hline original framework & Sep. 97 & Sep. 98 & 225 & & 448 & 157 & 291 & 29 & 54 & 14 & 760 \\
\hline enhanced framework & Feb. 00 & Jun. 01 & 150 & & 854 & 268 & 585 & 55 & 140 & 30 & 1,300 \\
\hline Burkina Faso & & & & & 553 & 83 & 469 & 57 & 231 & & 930 \\
\hline original framework & Sep. 97 & Jul. 00 & 205 & & 229 & 32 & 196 & 22 & 91 & 27 & 400 \\
\hline enhanced framework & Jul. 00 & Apr. 02 & 150 & & 195 & 35 & 161 & 22 & 79 & 30 & 300 \\
\hline topping-up & $\ldots$ & Apr. 02 & 150 & & 129 & 16 & 112 & 14 & 61 & 24 & 230 \\
\hline Cameroon & Oct. 00 & Apr. 06 & 150 & & 1,267 & 879 & 322 & 37 & 176 & 27 & 4,917 \\
\hline Ethiopia & & & & & 1,982 & 637 & 1,315 & 60 & 832 & & 3,275 \\
\hline enhanced framework & Nov. 01 & Apr. 04 & 150 & & 1,275 & 482 & 763 & 34 & 463 & 47 & 1,941 \\
\hline topping-up & & Apr. 04 & 150 & & 707 & 155 & 552 & 26 & 369 & 31 & 1,334 \\
\hline Gambia, The & Dec. 00 & Dec. 07 & 150 & & 67 & 17 & 49 & 2 & 22 & 27 & 112 \\
\hline Ghana & Feb. 02 & Jul. 04 & 144 & 250 & 2,186 & 1,084 & 1,102 & 112 & 781 & 56 & 3,500 \\
\hline Guyana & & & & & 591 & 223 & 367 & 75 & 68 & & 1,354 \\
\hline original framework & Dec. 97 & May 99 & 107 & 280 & 256 & 91 & 165 & 35 & 27 & 24 & 634 \\
\hline enhanced framework & Nov. 00 & Dec-03 & 150 & 250 & 335 & 132 & 202 & 40 & 41 & 40 & 719 \\
\hline Honduras & Jul. 00 & Mar-05 & 110 & 250 & 556 & 215 & 340 & 30 & 98 & 18 & 1,000 \\
\hline Madagascar & Dec. 00 & Oct-04 & 150 & & 836 & 474 & 362 & 19 & 252 & 40 & 1,900 \\
\hline Malawi & & & & & 1,057 & 171 & 886 & 45 & 622 & & 1,628 \\
\hline enhanced framework & Dec. 00 & Aug-06 & 150 & & 646 & 164 & 482 & 30 & 333 & 44 & 1,025 \\
\hline topping-up & $\ldots$ & Aug-06 & 150 & & 411 & 7 & 404 & 15 & 289 & 35 & 603 \\
\hline Mali & & & & & 539 & 169 & 370 & 59 & 185 & & 895 \\
\hline original framework & Sep. 98 & Sep. 00 & 200 & & 121 & 37 & 84 & 14 & 43 & 9 & 220 \\
\hline enhanced framework & Sep. 00 & Mar. 03 & 150 & & 417 & 132 & 285 & 45 & 143 & 29 & 675 \\
\hline Mauritania & Feb. 00 & Jun. 02 & 137 & 250 & 622 & 261 & 361 & 47 & 100 & 50 & 1,100 \\
\hline Mozambique & & & & & 2,023 & 1,270 & 753 & 143 & 443 & & 4,300 \\
\hline original framework & Apr. 98 & Jun. 99 & 200 & & 1,717 & 1,076 & 641 & 125 & 381 & 63 & 3,700 \\
\hline enhanced framework & Apr. 00 & Sep. 01 & 150 & & 306 & 194 & 112 & 18 & 62 & 27 & 600 \\
\hline Nicaragua & Dec. 00 & Jan. 04 & 150 & & 3,308 & 2,175 & 1,134 & 82 & 191 & 73 & 4,500 \\
\hline Niger & & & & & 663 & 235 & 428 & 42 & 240 & & 1,190 \\
\hline enhanced framework & Dec. 00 & Apr. 04 & 150 & & 521 & 211 & 309 & 28 & 170 & 53 & 944 \\
\hline topping-up & $\ldots$ & Apr. 04 & 150 & & 143 & 23 & 119 & 14 & 70 & 25 & 246 \\
\hline Rwanda & & & & & 696 & 65 & 631 & 63 & 383 & & 1,316 \\
\hline enhanced framework & Dec. 00 & Apr-05 & 150 & & 452 & 56 & 397 & 44 & 228 & 71 & 839 \\
\hline topping-up & $\ldots$ & Apr-05 & 150 & & 243 & 9 & 235 & 20 & 154 & 53 & 477 \\
\hline São Tomé and Príncipe & & & & & 124 & 31 & 93 & - & 47 & 128 & 263 \\
\hline enhanced framework & Dec. 00 & Mar-07 & 150 & & 99 & 29 & 70 & - & 24 & 83 & 215 \\
\hline topping-up & $\ldots$ & Mar-07 & 150 & & 25 & 2 & 23 & - & 23 & 45 & 49 \\
\hline Senegal & Jun. 00 & Apr. 04 & 133 & 250 & 488 & 212 & 276 & 45 & 124 & 19 & 850 \\
\hline Sierra Leone & Mar. 02 & Dec. 06 & 150 & & 675 & 335 & 340 & 125 & 123 & 81 & 994 \\
\hline Tanzania & Apr. 00 & Nov. 01 & 150 & & 2,026 & 1,006 & 1,020 & 120 & 695 & 54 & 3,000 \\
\hline Uganda & & & & & 1,003 & 183 & 820 & 160 & 517 & & 1,950 \\
\hline original framework & Apr. 97 & Apr. 98 & 202 & & 347 & 73 & 274 & 69 & 160 & 20 & 650 \\
\hline enhanced framework & Feb. 00 & May 00 & 150 & & 656 & 110 & 546 & 91 & 357 & 37 & 1,300 \\
\hline Zambia & Dec. 00 & Apr-05 & 150 & & 2,499 & 1,168 & 1,331 & 602 & 493 & 63 & 3,900 \\
\hline \multicolumn{12}{|c|}{ Decision point reached under enhanced framework (10) } \\
\hline Afghanistan & Jul. 07 & Floating & 150 & & 571 & 436 & 135 & - & 75 & 51 & 1,272 \\
\hline Burundi & Aug. 05 & Floating & 150 & & 826 & 124 & 701 & 28 & 425 & 92 & 1,465 \\
\hline Central African Rep. & Sept. 07 & Floating & 150 & & 583 & 217 & 365 & 27 & 209 & 68 & 782 \\
\hline Chad & May. 01 & Floating & 150 & & 170 & 35 & 134 & 18 & 68 & 30 & 260 \\
\hline Congo, Democratic Rep. of & Jul. 03 & Floating & 150 & & 6,311 & 3,837 & 2,474 & 472 & 831 & 80 & 10,389 \\
\hline Congo Rep. of & Mar. 06 & Floating & & 250 & 1,679 & 1,561 & 118 & 8 & 49 & 32 & 2,881 \\
\hline Guinea & Dec. 00 & Floating & 150 & & 545 & 215 & 328 & 31 & 152 & 32 & 800 \\
\hline Guinea-Bissau & Dec. 00 & Floating & 150 & & 416 & 212 & 204 & 12 & 93 & 85 & 790 \\
\hline Haiti & Nov. 06 & Floating & 150 & & 140 & 20 & 120 & 3 & 53 & 15 & 213 \\
\hline Total assistance provided/committed & & & & & 35,996 & 17,618 & 18,279 & $2,635 \quad 3 /$ & 8,780 & 1,102 & 62,973 \\
\hline
\end{tabular}

Sources: IMF and World Bank Board decisions, completion point documents, decision point documents, preliminary HIPC documents, and staff calculations.

1/ Assistance levels are at countries' respective decision or completion points, as applicable

2/ In percent of the net present value of debt at the decision or completion point (as applicable), after the full use of traditional debt-relief mechanisms.

3/ Equivalent to SDR 1,698 million at an SDR/USD exchange rate of 0.644524, as of October 4, 2007. 


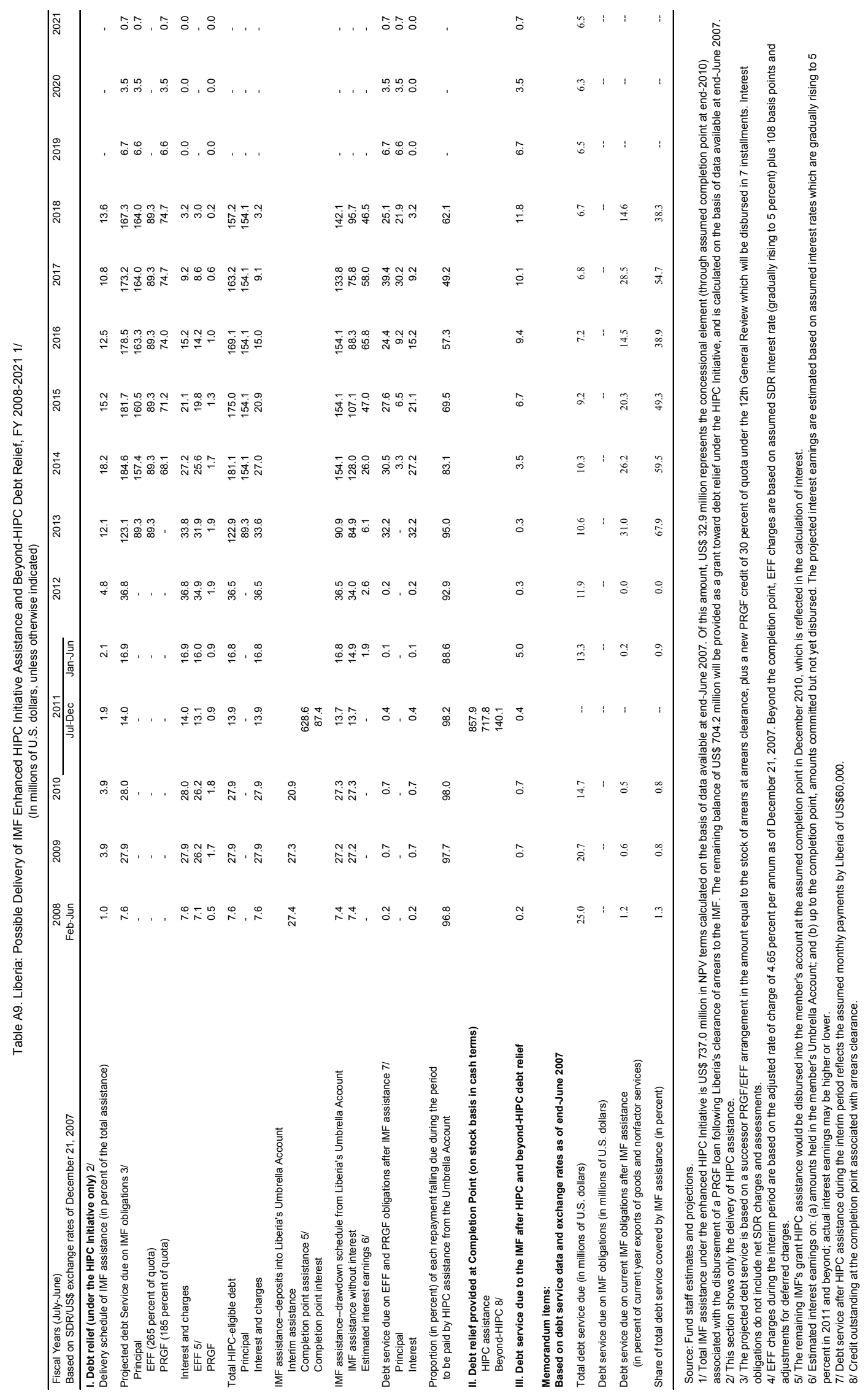


Table A10: Paris Club Creditors' Delivery of Debt Relief Under Bilateral Initiatives Beyond the HIPC Initiative 1/

\begin{tabular}{|c|c|c|c|c|c|c|c|}
\hline & \multirow{2}{*}{$\begin{array}{l}\text { Countries covered } \\
\text { (1) } \\
\end{array}$} & \multicolumn{2}{|c|}{ ODA (in percent) } & \multicolumn{2}{|c|}{ Non-ODA (in percent) } & \multicolumn{2}{|c|}{ Provision of relief } \\
\hline & & $\begin{array}{r}\text { Pre-cutoff date debt } \\
\text { (2) } \\
\end{array}$ & $\begin{array}{r}\text { Post-cutoff date debt } \\
\text { (3) } \\
\end{array}$ & $\begin{array}{r}\text { Pre-cutoff date debt } \\
\qquad(4) \\
\end{array}$ & $\begin{array}{r}\text { Post-cutoff date debt } \\
\text { (5) }\end{array}$ & $\begin{array}{r}\text { Decision point } \\
\text { (percent) } \\
(6) \\
\end{array}$ & $\begin{array}{r}\text { Completion } \\
\text { point } \\
(7) \\
\end{array}$ \\
\hline Australia & HIPCs & 100 & 100 & 100 & $1002 /$ & $-2 /$ & $-2 /$ \\
\hline Austria & HIPCs & 100 & - & 100 & - & Case-by-case, flow & Stock \\
\hline Belgium & HIPCs & 100 & 100 & 100 & - & 100 flow & Stock \\
\hline Canada & HIPCs 3/ & $-4 /$ & $-4 /$ & 100 & 100 & 100 flow & Stock \\
\hline Denmark & HIPCs & 100 & $1005 /$ & 100 & $1005 /$ & 100 flow & Stock \\
\hline France & HIPCs & 100 & 100 & 100 & - & 100 flow $6 /$ & Stock \\
\hline Finland & HIPCs & 100 & $-7 /$ & 100 & $-7 /$ & - & - \\
\hline Germany & HIPCs & 100 & 100 & 100 & 100 & 100 flow & Stock \\
\hline Ireland & - & - & - & - & - & - & - \\
\hline Italy & HIPCs & 100 & $1008 /$ & 100 & $1008 /$ & 100 flow & Stock \\
\hline Japan & HIPCs & 100 & 100 & 100 & - & - & Stock \\
\hline Netherlands, the & HIPCs & $1009 /$ & 100 & 100 & - & 90-100 flow 9/ & Stock $9 /$ \\
\hline Norway & HIPCs & $-10 /$ & $-10 /$ & $-11 /$ & $-11 /$ & - & - \\
\hline Russia & HIPCS & $-12 /$ & $-12 /$ & 100 & 100 & - & Stock \\
\hline Spain & HIPCs & 100 & Case-by-case & 100 & Case-by-case & - & Stock \\
\hline Sweden & HIPCs & - & $-13 /$ & 100 & - & - & Stock \\
\hline Switzerland & HIPCs & $-14 /$ & $-14 /$ & $90-100 \quad 15 /$ & - & 90-100 flow & Stock \\
\hline United Kingdom & HIPCs & 100 & 100 & 100 & $10016 /$ & 100 flow $16 /$ & Stock \\
\hline United States & HIPCs & 100 & 100 & 100 & $10017 /$ & 100 flow & Stock \\
\hline
\end{tabular}

Source: Paris Club Secretariat.

1/ Columns (1) to (7) describe the additional debt relief provided following a specific methodology under bilateral initiatives and need to be read as a whole for each creditor. In column (1), "HIPCs" stands for eligible countries effectively qualifying for the HIPC process. A "100 percent" mention in the table indicates that the debt relief provided under the enhanced HIPC Initiative framework will be topped up to 100 percent through a bilateral initiative.

2/ Australia: post-cutoff date non-ODA relief to apply to debts incurred before a date to be finalized; timing details for both flow and stock relief are to be finalized.

3/ Canada: including Bangladesh. Canada has granted a moratorium of debt service as of January 2001 on all debt disbursed before end-March 1999 for 13 out of 17 HIPCs

with debt service due to Canada. Eligible countries are Benin, Bolivia, Cameroon, Dem. Rep. of Congo, Ethiopia, Ghana, Guyana, Honduras, Madagascar, Rwanda, Senegal,

Tanzania, and Zambia. 100\% cancellation will be granted at completion point. As of July 2004, Canada has provided completion point stock of debt cancellation for Benin,

Bolivia, Guyana, Senegal, and Tanzania.

4/ 100 percent of ODA claims have already been cancelled on HIPCs, with the exception of Myanmar's debt to Canada.

5/ Denmark provides 100 percent cancellation of ODA loans and non-ODA credits contracted and disbursed before September 27, 1999.

6/ France: cancellation of 100 percent of debt service on pre-cutoff date commercial claims on the government as they fall due starting at the decision point. Once

countries have reached their completion point, debt relief on ODA claims on the government will go to a special account and will be used for specific development projects.

7/ Finland: no post-COD claims

8/ Italy: cancellation of 100 percent of all debts (pre- and post-cutoff date, ODA and non-ODA) incurred before June 20, 1999 (the Cologne Summit). At decision point, cancellation of the related amounts falling due in the interim period. At completion point, cancellation of the stock of remaining debt.

9/ The Netherlands: 100 percent ODA (pre- and post-cutoff date debt will be cancelled at decision point); for non-ODA: in some particular cases (Benin, Bolivia,

Burkina Faso, Ethiopia, Ghana, Mali, Mozambique, Nicaragua, Rwanda, Tanzania, Uganda, and Zambia), the Netherlands will write off 100 percent of the consolidated amounts

on the flow at decision point; all other HIPCs will receive interim relief up to 90 percent reduction of the consolidated amounts. At completion point, all HIPCs will receive

100 per cent cancellation of the remaining stock of the pre-cutoff date debt.

10/ Norway has cancelled all ODA claims.

11/ Due to the current World Bank/IMF methodology for recalculating debt reduction needs at HIPC completion point, Norway has postponed the decisions on whether or

not to grant $100 \%$ debt reduction until after the completion point.

12/ Russia has no ODA claims

13/ Sweden has no ODA claims.

14/ Switzerland has cancelled all ODA claims.

15/ In some particular cases (Central African Republic, Liberia, Republic of Congo, Sierra Leone, Togo), Switzerland will write off 100 percent of the remaining debt stock at

completion point; all other HIPCs will receive debt relief according to Paris Club terms.

16/ United Kingdom: "beyond 100 percent" full write-off of all debts of HIPCs as of their decision points, and reimbursement at the decision point of any debt service

paid before the decision point.

17/ United States: 100 percent post-cutoff date non-ODA treated on debt assumed prior to June 20, 1999 (the Cologne Summit). 


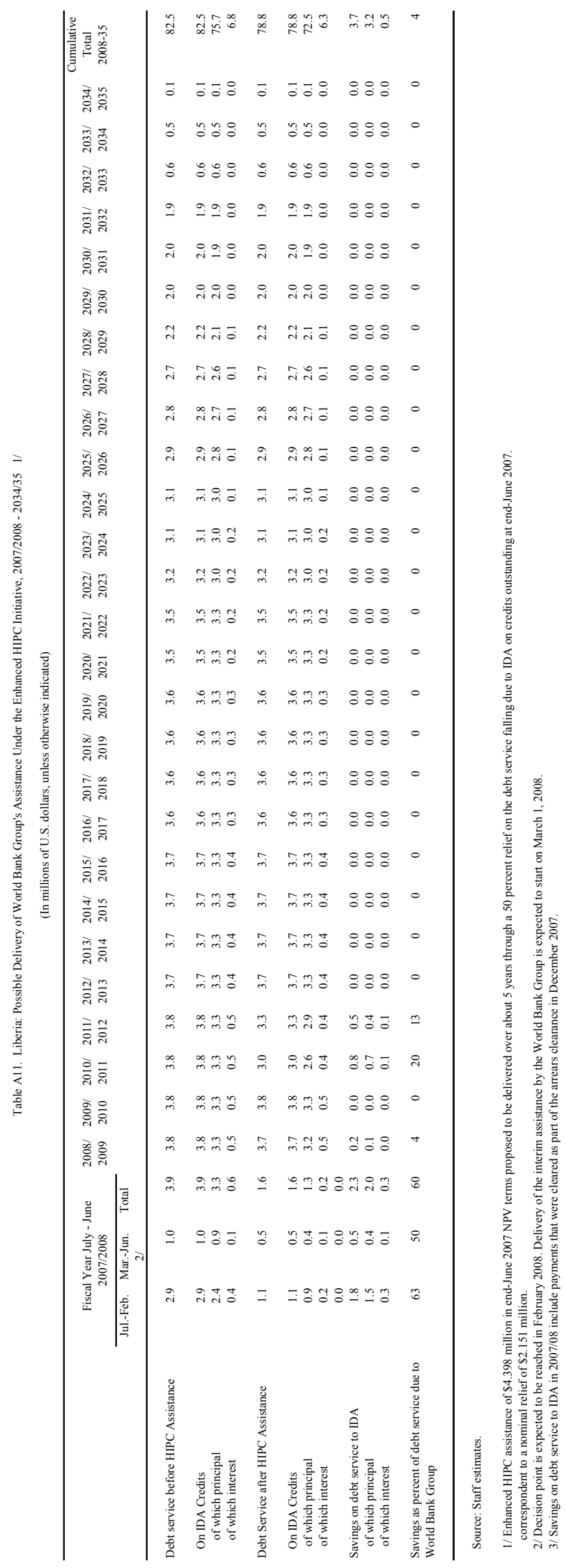




\section{ANNEX I \\ Liberia: Debt Management}

1. Prolonged civil conflict in Liberia has severely disrupted the capacity of the various institutions that are responsible for debt management. Since the mid-1980s, the government has been unable to service its debts. The large accumulation of arrears has curtailed Liberia's access to new financing and thus financing is available only in the form of grants. These events have weakened debt management processes as institutional capacity has weakened, and established procedures and practices have broken down.

2. This annex documents the institutional and legal framework as well as the current practices and capacity of the agencies responsible for debt management in Liberia.

\section{Institutional and Legal Framework}

3. Debt management in the Republic of Liberia is the responsibility of the Ministry of Finance and the Central Bank of Liberia (CBL). The existing legislation does not clearly specify the different tasks of each institution or its responsibility for designing and implementing a cohesive debt strategy.

4. There are four pieces of legislation that constitute the legal framework to regulate debt management in Liberia:

- $\quad$ The constitution of 1986 states in article 34 that "no loan shall be raised by the government on behalf of the Republic or guarantees given for any public institution or authority otherwise than by or under the authority of legislative enactment."

- $\quad$ The executive law creating the Ministry of Finance, Chapter 21.3, states that one of the duties of the Deputy Minister of Finance for fiscal affairs is debt management. ${ }^{35}$

- $\quad$ The Revenue Code of Liberia Act of 2000 states in Section 2300 that "the president is authorized and empowered to negotiate, conclude and contract with any individual group, foreign government or any financial institution at home or abroad, long or short term loans for the overall development of the country." Section 2301 gives the president the power to guarantee loans to state-owned enterprises (SOEs).

- $\quad$ The 1999 Act to Authorize the Establishment of the CBL regulates the functions of the CBL. It lists among the functions of the CBL "to provide credit to bank-financial institutions on a discretionary basis" and to "advise the central bank on financial and

\footnotetext{
${ }^{35}$ Debt management is now the responsibility of the Deputy Minister of Finance for Expenditure and Debt Management.
} 
economic matters." Part VI of the Act states that the central bank may "contract, purchase, and market financial instruments, debt obligations rated in one of the two highest rating categories recognized by reputed international credit rating agencies, and other securities issued or guaranteed by foreign central banks, governments or international financial institutions." Part VII states that the central bank may purchase from, sell to, discount and re-discount for, or contract with financial institution treasury bills. Part VIII regulates central bank credits to the government.

\section{Debt Recording and Statistics}

5. The Debt Management Unit (DMU) of the Ministry of Finance is now the main source of public debt statistics. The DMU recently completed a review of domestic debt, with assistance from KPMG Ghana. As part of the HIPC process, Liberia has undertaken a preliminary reconciliation of multilateral and bilateral external debt, with assistance from the World Bank and IMF. Houlihan Lokey (financial consultants) were contracted by the government with support from the government of Switzerland to work on the reconciliation of commercial creditor data.

6. No comprehensive public debt database currently exists. The Unit does not have any debt recording software installed. Instead, debt data is stored in various Excel spreadsheets. The work processes of the DMU are constrained by its limited technological capacity. Also, there are no standard procedures to monitor and record incoming data, no explicit access controls or data back-up procedures for data records, and no clear division of responsibility between individual staff members.

7. Many original loan agreements that were lost or destroyed during the civil conflict are missing from the archives. Loan documentation is not filed in a systematic manner and is not kept in a secure archive.

\section{Debt Strategy and New Borrowing}

8. Currently, the debt strategy consists solely of the domestic debt resolution strategy, largely because debt flows have been very limited during the past two decades owing to the civil conflict. As Liberia has yet to produce both a debt and new financing strategy, it has yet to establish appropriate procedures for contracting new financing. Furthermore, a domestic debt issuance policy has yet to be developed and implemented. The government has made clear, however, that it proposes in the next few years to follow a "no borrowing" strategy.

\section{Contingent Liabilities and Guarantees}

9. There are currently no formal procedures to monitor the contracting of debt by SOEs. Unless the creditor requires a state guarantee, SOEs currently do not need ministerial approval to take on new debts. The last guarantee was provided to Liberian Electricity Corporation in 2002 following a request from ECOBANK. The Bureau of State Enterprises 
(BSE) is the government agency that is responsible for monitoring the financial performance of SOEs. Any potential financial problems are to be flagged for the Ministry of Finance at an early stage so as to minimize the risk of debt default. A significant portion of the government's existing domestic debt has been inherited from SOEs that have defaulted on their debt obligations.

\section{Debt Servicing and Projections}

10. The process for servicing obligations starts at the DMU which sends a payment order to the Controller General, who, after approving, would forward it to the Deputy Minister of Expenditure and Debt for signature, and then on to the CBL. As the depositary of the Treasury, the CBL conducts debt payments. Although this is still the formal procedure, in reality, there has not been systematic coordination with the Ministry of Finance before payment instructions are sent to the CBL, in part because only small "good will" payments are currently being made to the IMF, World Bank Group, and AfDB Group.

11. Despite plans to obtain CS-DRMS 2000+, the government does not currently use any computerized debt strategy tool. A lack of a reliable debt recording system severely limits the government's capacity to make reliable debt service projections.

\section{Publication and Transparency}

12. No national debt report is currently produced. Various publications/sources contain some basic debt statistics. These include:

- The annual report of the MOF. The Bureau of Concessions leads an interdepartmental team to prepare the Annual Report. The last report published was for 2006.

- Annual budget. The annual budget includes some provisions for debt servicing, but no debt stock data.

- $\quad$ The Quarterly Economic Bulletin (QEB) produced by the CBL. The appendix tables summarizes Liberia's public debt by quarter and by creditor type using data from the Ministry of Finance. Another table contains the monetary survey that displays domestic credit claims on the general government and public corporations by quarter. The QEB is disseminated to the wider public and usually published within three to six months of the reference period.

\section{Staffing and Capacity}

13. The Ministry of Finance's DMU employs seven staff members. Only two staff members are employed in a technical capacity; the other staff members work in a supportive 
role. The Debt Unit of the CBL employs two staff. The DMU has limited office space and it has an unreliable internet connection.

14. One Ministry of Finance staff member attended a CS-DRMS course in July 2005 but never applied the knowledge and was thus unable to retain it. Two CBL technical staff members and one Ministry of Finance technical staff member attended a Debt Sustainability Analysis workshop organized by the World Bank in March 2007. Applications are pending for Ministry of Finance staff to attend Loan Negotiation and Evaluation and Debt Restructuring courses provided by the Crown Agents and the External Debt Statistics course of the IMF.

\section{Recent Reform Measures}

15. In an effort to coordinate debt management, the Liberian Government created the Debt Management Task Force (DMTF) in April 2004. The body was represented by the CBL, Ministry of Finance, Ministry of Planning and Economic Affairs, General Auditing Office and the Bureau of the Budget. This task force was temporarily successful in reconciling domestic debt data and was able to effect some degree of cooperation and coordination between the different institutions involved in debt management. However, apparently in part because of lack of funding, the DMTF ceased to exist from end-2005. Until recently, very little information was being circulated between the institutions and departments involved in debt management.

\section{Future Reforms Required}

16. The institutions participating in the debt management process will be able to cope with the tasks under their responsibility only if their capacity is increased significantly. The first challenge is to start producing accurate public debt statistics, inclusive of SOEs, on a timely basis and to make them publicly available via a periodically published debt report. The government also needs to design and implement a debt management strategy, including borrowing by SOEs. Support from the international community will be critical for achieving these goals. 


\section{ANNEX II \\ Liberia: Proposed Methodology for Imputing Value of Services Receipts ${ }^{36}$}

17. Lack of official or other reliable source data on services receipts precluded the usual calculation of the net present value of external debt to exports (goods and services) to assess Liberia's eligibility for the Heavily Indebted Poor Countries (HIPC) Initiative. It was, therefore, necessary to impute the value of services receipts.

18. Staff has used historic comparator country data to derive a benchmark ratio of services receipts ${ }^{37}$ to merchandise exports. This ratio was then applied to existing Liberian data for merchandise exports to impute the value of services receipts for the periods required.$^{38}$ There were three main considerations in deciding how to undertake these estimates: (a) choice of comparator country group; (b) data from which to derive the ratio; and (c) time period over which to sample data.

19. The comparator country group includes countries that are (a) both PRGF-eligible and included in the World Bank's group of low-income countries (WB LIC); and (b) post-conflict. It was determined on the basis of having reviewed several groups of countries with shared characteristics (Box II.A).

- $\quad$ Using the PRGF-eligibility criterion alone was deemed not sufficiently robust given the large variation in the results (Table II.1). Applying a stricter income criterion (i.e., limiting the sample to the countries below the World Bank's low-income classification 2005 cutoff of $\$ 875$ per capita) was considered an objective basis on which to refine the group given Liberia's likely extremely low per capita income.

- Furthermore, it appeared appropriate to further refine the comparator group based on low-income countries with shared characteristics that are obvious impediments to trade in services, such as a history of conflict.

\footnotetext{
${ }^{36}$ This methodology is similar to the one developed and used in the case of Afghanistan and that was endorsed by the Boards of IDA and the IMF during their discussion of the HIPC preliminary document for this country.

${ }^{37}$ In the IMF's Balance of Payments Manual (fifth edition) services cover travel and transportation as well as communication services, construction services, financial and insurance services, various business-related services (e.g., computer services), and government services (e.g., goods and services purchases by embassies).

${ }^{38}$ Exports of goods and services data were required for 2003/04-05/06 for the preliminary DRA presented in this document.
} 


\section{Box II.A: Overview of Comparator Country Group and Criteria}

- $\quad$ The proposed comparator country group and each of the subgroups are summarized here.

- The proposed comparator country group of low-income countries that are post-conflict covers 18 countries: Burundi, Cambodia, Central African Republic, Chad, Democratic Republic of Congo, Côte d'Ivoire, Ethiopia, Guinea, Guinea-Bissau, Haiti, Mozambique, Niger, Rwanda, Sierra Leone, Sudan, Tajikistan, Timor Leste, and Yemen.

- Of these, PCCs were identified on the basis of a country's access to the IMF's Emergency Post-Conflict Assistance and various IMF research papers (e.g., Occasional Paper No. 247, Rebuilding Fiscal Institutions in Post Conflict Countries), supplemented by information from the "mag" index from the Armed Conflict and Intervention Project of the Center for Systemic Peace at the University of Maryland (http://members.aol.com/cspmgm/warlist.htm). Key features of PCCs included deteriorating governance, prolonged political crisis, post-conflict transition, and gradual but still fragile reform processes (http://members.aol.com/cspmgm/warlist.htm).

20. The time period for calculating the benchmark ratio was chosen to cover the longest available data time frame (1980-2005). Consideration was given to the possible relationship between the performance of services receipts in other PCCs in the periods preceding and following the conflict. Conceptually, a conflict could potentially have different impacts on merchandise exports than on services. This could reflect severe damage to infrastructure or the presence of foreigners. However, the lack of consistent data over time for these countries made it impossible to identify such patterns.

21. Results for estimates of Liberian services receipts. While the use of estimates may draw criticism regarding the subjectivity and uncertainty of results, they represent a practical solution to a seemingly intractable problem. The results are presented in Table II.1.

- $\quad$ The criteria for defining the comparator country group are both relatively objective and well-justified.

- The benchmark ratio of total services receipts to merchandise exports in comparator countries is a sound choice given the limited range of data available in Liberia and comparator countries.

- $\quad$ Although the proposed benchmark ratio (38.0 percent) may err on the side of being too high to avoid criticism of under-estimation (and over-estimating of HIPC debt 
relief), ${ }^{39}$ it represents a pragmatic middle ground. The results do not seem out of line with other groups. They are comparable with the results for all HIPCs, with the benchmark ratio for the comparator group (38.0 percent) falling between the median (26.5 percent) and average (42.8 percent) for HIPCs (Figure II.1)

\footnotetext{
${ }^{39}$ If, before a country reaches the completion point, there are revisions to the data (debt or economic) used in the decision point DRA, a revised DRA will be prepared. Adjustments to the amount of HIPC debt relief will depend on the nature of data revisions. First, for revisions to the export data provided by, or at the behest of, the member (e.g., official merchandise export data for the period covered by the decision point NPV ratio (i.e., 2003/04-2005/06)), the amount of debt relief can be adjusted upward or downward (if it exceeds or falls short of the de minims 1 percent threshold specified in the HIPC Trust Instrument). Second, adjustments in HIPC debt relief attributable to incorrect information on export data that was not provided by, or at the behest of, the member (e.g., staff estimates of the ratio between total services receipts to merchandise exports) would only be made if they lead to higher assistance. Given that Paris Club creditors are likely to provide 100 percent relief in the context of the HIPC Initiative, any revised debt relief calculations would ultimately only affect the time profile with which their claims are forgiven. However, the amount of HIPC debt relief to be provided by other creditors could be affected.
} 
Table II.1. Republic of Liberia: Estimates of Services Receipts

\begin{tabular}{|c|c|c|c|c|c|c|}
\hline & $\begin{array}{c}\text { Services } \\
\text { Ratio 1/ }\end{array}$ & $2001 / 02$ & $2002 / 03$ & 2003/04 & $2004 / 05$ & 2005/06 \\
\hline & (Percent) & \multicolumn{5}{|c|}{ (Millions of US dollars) } \\
\hline Merchandise Exports 2/ & & 147 & 138 & 106 & 107 & 134 \\
\hline \multicolumn{7}{|l|}{ Services Receipts } \\
\hline Current IMF Estimates in BoP & & 25 & 24 & 19 & 20 & 21 \\
\hline Comparator Group: Post-conflict and PRGF Eligible & 38 & 56 & 52 & 40 & 41 & 51 \\
\hline \multicolumn{7}{|l|}{ Other Country Groups } \\
\hline Post-Conflict (all) & 38 & 56 & 52 & 40 & 41 & 51 \\
\hline WB LIC & 40 & 59 & 55 & 43 & 43 & 54 \\
\hline WB IDA-only & 68 & 101 & 94 & 73 & 73 & 92 \\
\hline PRGF-eligible & 70 & 103 & 97 & 75 & 75 & 94 \\
\hline
\end{tabular}

1/ Comparator ratio derived from the IMF's Balance of Payments Yearbook (database) based on data covering 1980-2005.

2/ IMF estimates. 
Figure II.1. Service Credits as a percentage of Merchandise Exports in HIPCs

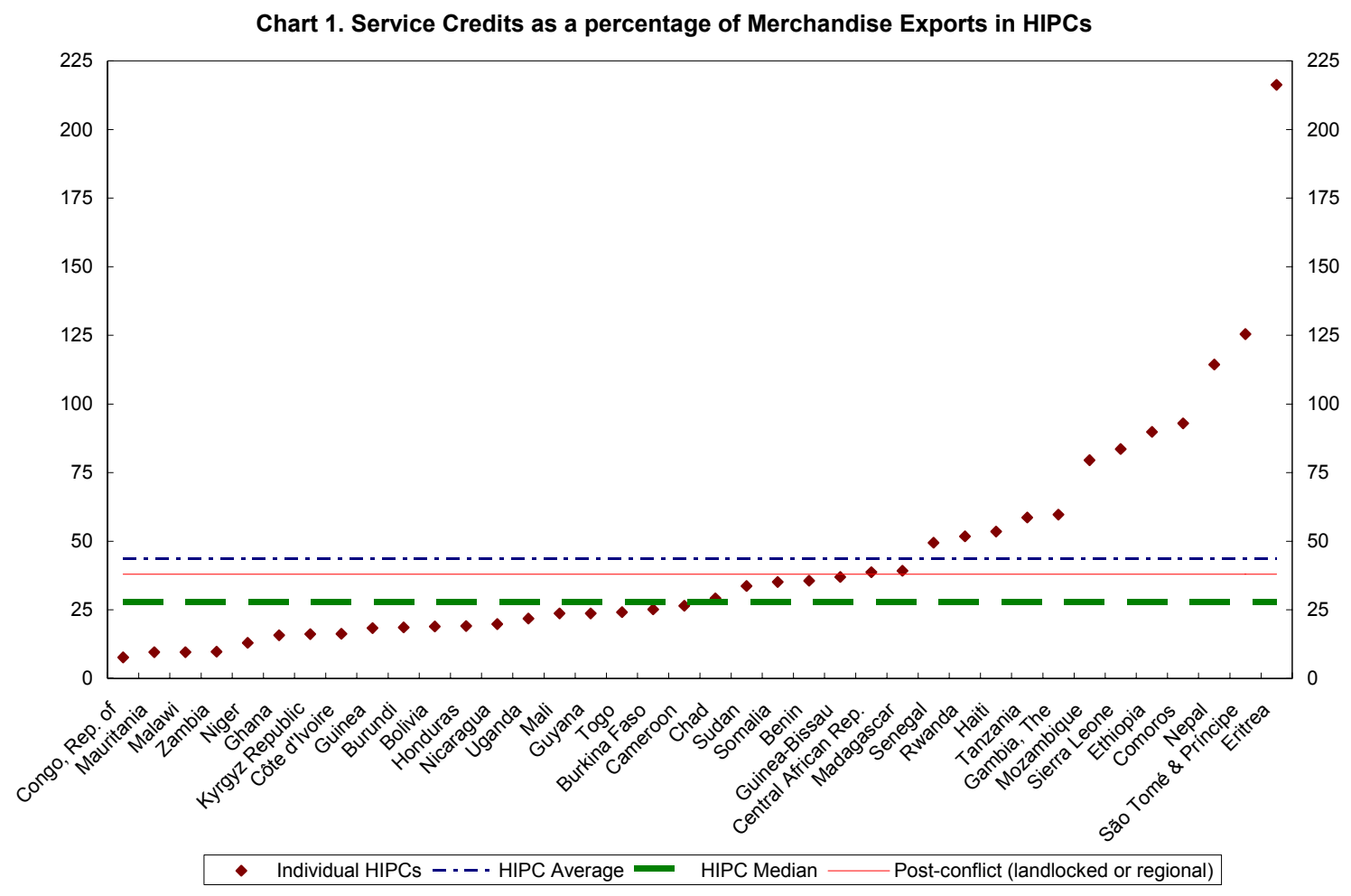

